\title{
DESIGN AND OPERATIONS MANUAL PRESSURIZED IRRIGATION SYSTEMS VOLUME II
}

\author{
Shehzad Ahmad ${ }^{1}$ Ali Ajaz ${ }^{2}$
}

${ }^{1}$ Design Engineer (HEIS) ${ }^{2}$ Assistant Design Engineer (HEIS)

Document type: Technical Report

Volume: II

Publisher: Project- Implementation Supervision Consultants (PSC)

Month Published: April, 2014

DOI: 10.13140/RG.2.2.31028.76162
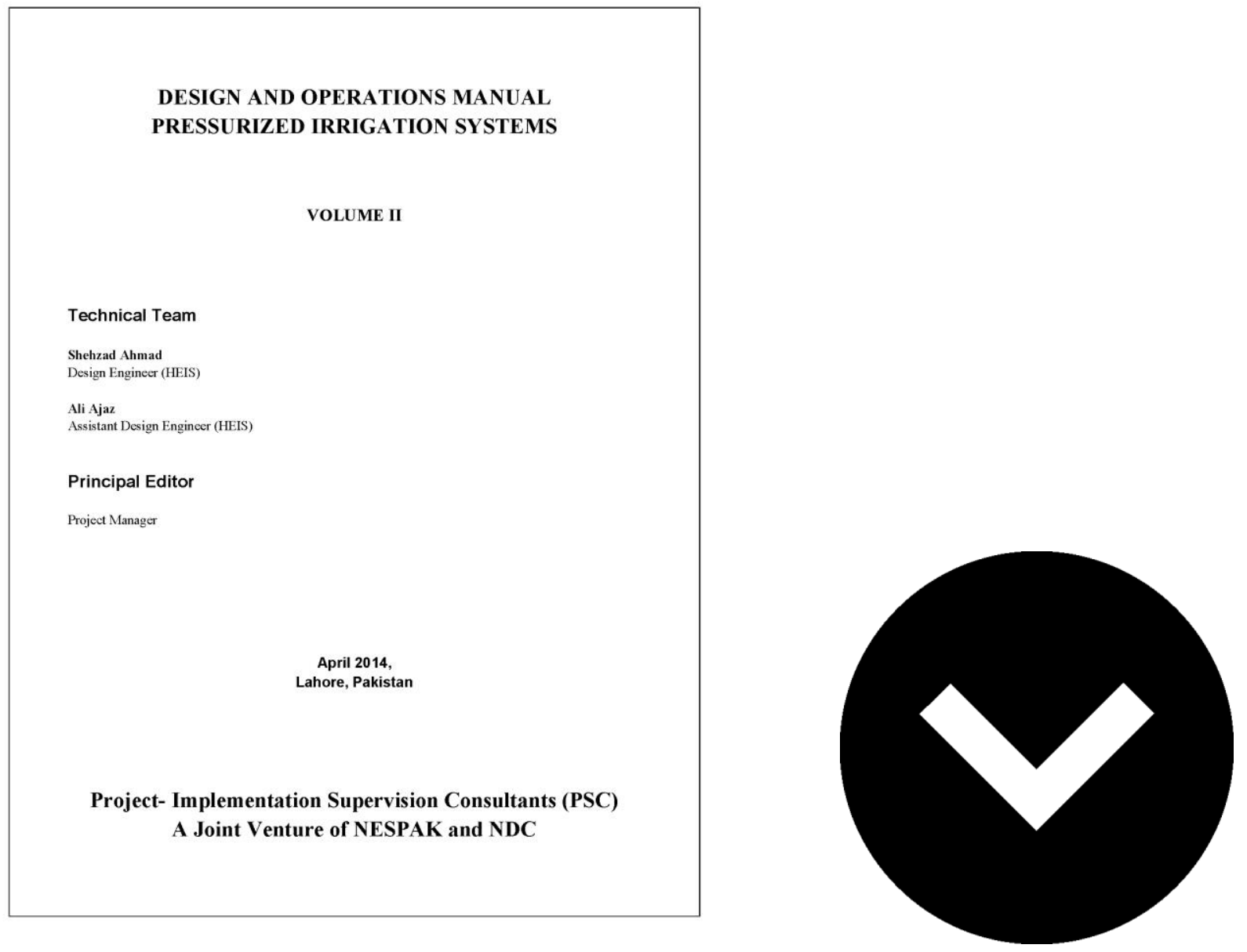


\title{
DESIGN AND OPERATIONS MANUAL PRESSURIZED IRRIGATION SYSTEMS
}

\author{
VOLUME II
}

\section{Technical Team}

Shehzad Ahmad

Design Engineer (HEIS)

Ali Ajaz

Assistant Design Engineer (HEIS)

\section{Principal Editor}

Project Manager

April 2014, Lahore, Pakistan

\section{Project- Implementation Supervision Consultants (PSC) A Joint Venture of NESPAK and NDC}




\section{PREFACE}

This draft manual covers the technical design and operational aspects of high efficiency (pressurized) irrigation system in a brief and comprehensive way. The first volume covers a detail discussion of pressurized irrigation systems including their classifications, selection criteria and components followed by basics of design. Design proforma for design of drip and sprinkler irrigation system has been discussed in detail covering the procedure for collection of necessary field data required for proper system design. Hydraulic principles have also been covered in detail for proper selection of pipe network and pumping unit. Design procedure has been elaborated with solved examples. Second volume of this manual covers the operational part of pressurized irrigation systems, which includes general maintenance and tips for durability and sustainability of high efficiency irrigation system equipments. It also covers the vigilance and checking during system operation, care after completing a crop season, care of prime movers, system re-adjustments, clogging and its remedies, chemigation including acid treatment and chlorination, maintenance tips of water storage tanks, general trouble shooting and remedies. A list of tables and diagrams is also provided for the ease of users. This manual will provide a general guideline to project technical staff and contractors for proper design and smooth field operations of high efficiency irrigation system sites and it will also be helpful for effective post installation services and getting the desired results from high efficiency irrigation systems. 


\section{DESIGN OPERATION AND MAINTENANCE MANUAL \\ FOR \\ HIGH EFFICIENCY IRRIGATION SYSTEMS \\ Vol II \\ TABLE OF CONTENTS}

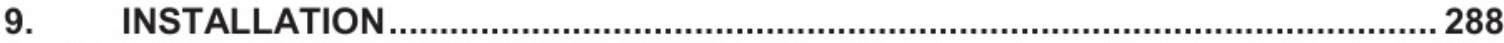

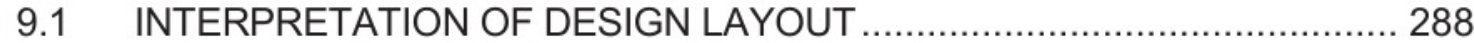

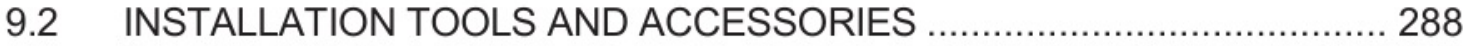

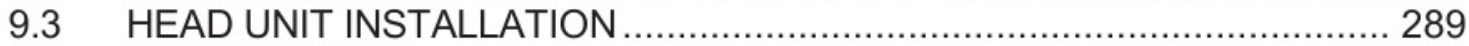

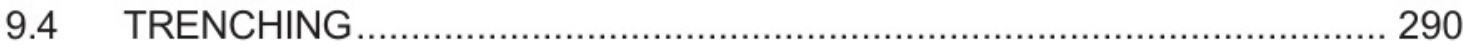

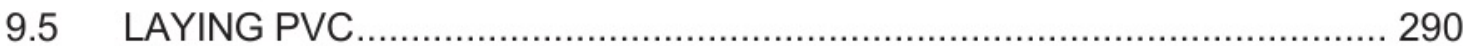

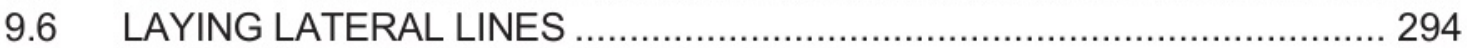

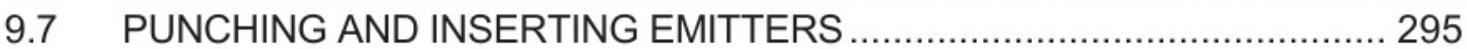

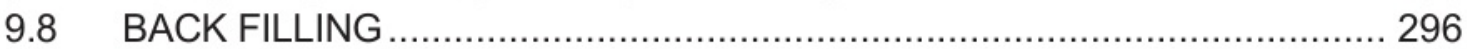

9.9 TESTING AND COMMISSIONING .................................................. 297

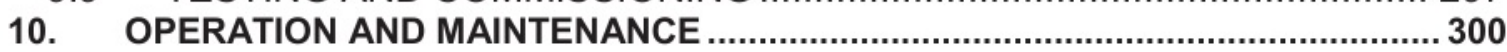

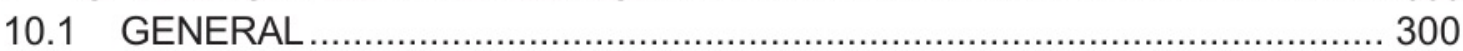

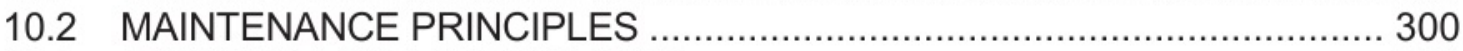

10.3 GENERAL MAINTENANCE TIPS ................................................ 301

10.4 CHECKING PRIOR TO STARTING (DAILY CHECKS) ......................... 302

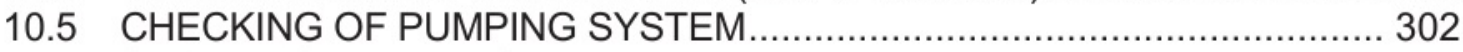

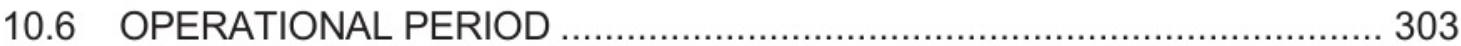

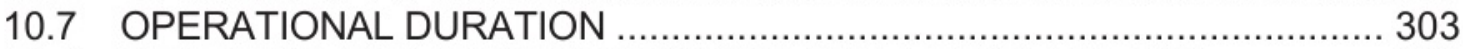

10.8 VIGILANCE AND CHECKING DURING SYSTEM OPERATION .............. 303

10.8.1 Water Flow Rate and Flow-Meter Observations................................... 304

10.8.2 Checking of Pressure Gauges and System Flushing ........................... 304

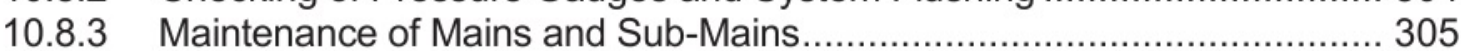

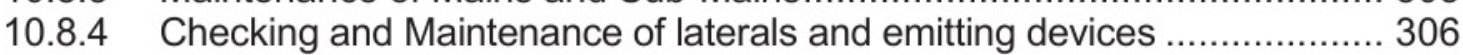

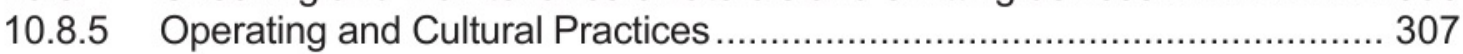

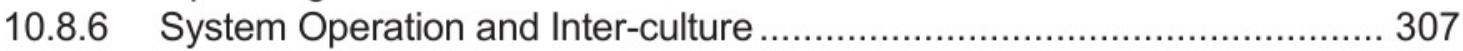

10.8.7 Care after Completing an Irrigation Cycle ........................................ 308

10.9 CARE AFTER COMPLETING A CROPPING SEASON ......................... 308

10.9.1 General operational problems and troubleshooting.............................. 309

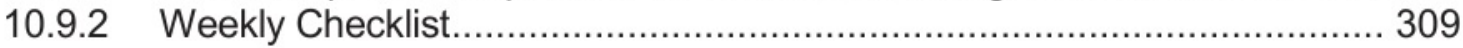

10.10 CARE AND CHECKING OF PRIME-MOVER ...................................... 309

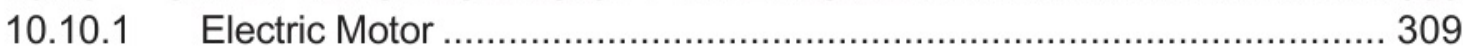

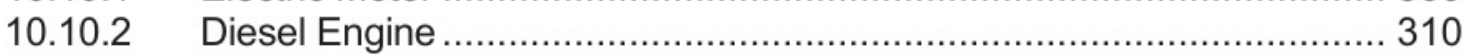

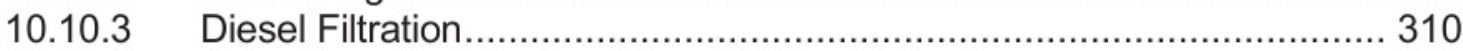

10.10.4 Selection of Lubrication Oil and Filling Method .................................... 310

10.11 MAINTENANCE OF WATER STORAGE TANK .............................. 311

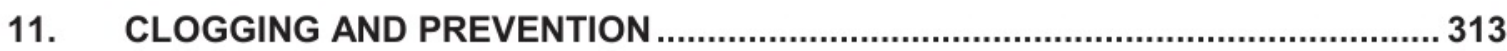

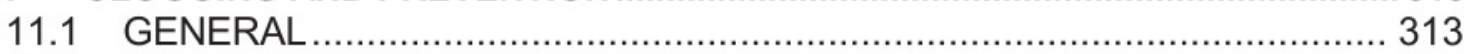

11.2 CAUSE OF CLOGGING AND PLUGGING ..................................... 314

11.3 SYSTEN COMPONENTS SENSITIVE TO CLOGGING ....................... 315

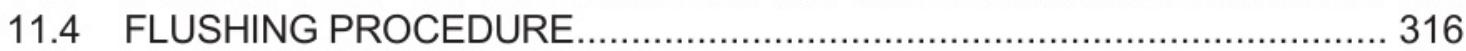

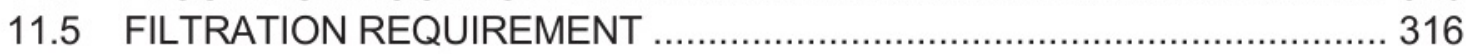

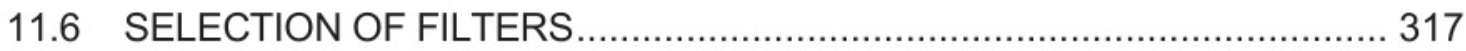

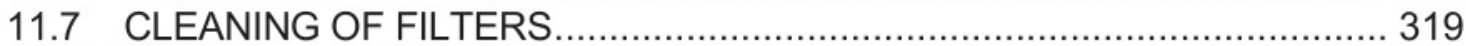

11.7.1 Flushing of Hydrocyclone Filters (Sand Separator) .............................. 319

11.7.2 Washing of Screen Filter ............................................................ 320 


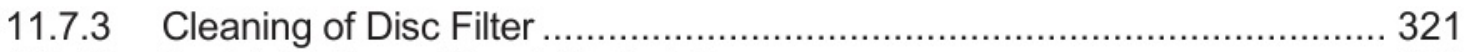

11.7.4 Back Flushing of Sand Media Filters ............................................ 322

11.8 SYSTEM RE-ADJUSTMENT - POSSIBILITIES AND LIMITATIONS ........... 323

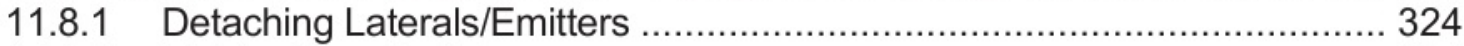

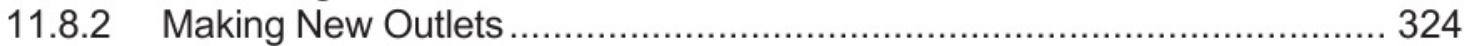

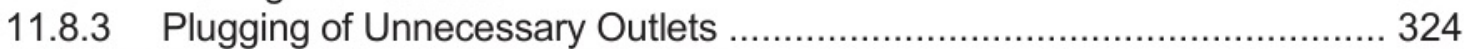

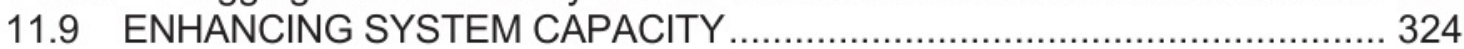

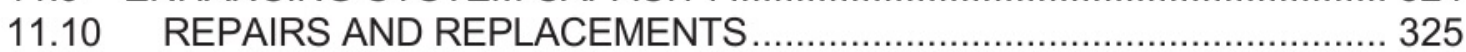

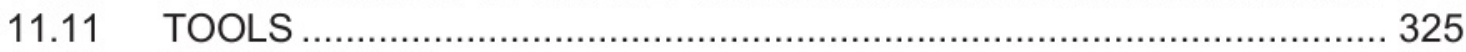

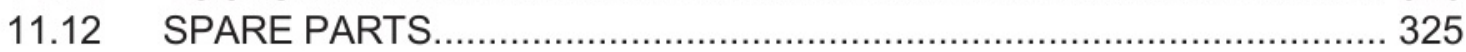

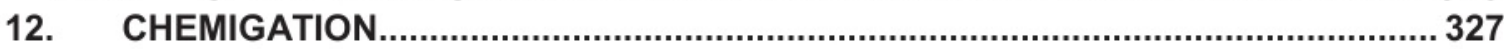

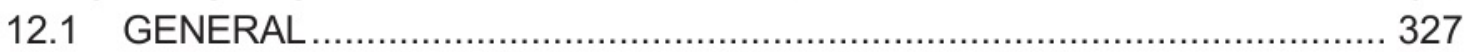

12.2 ACIDIFICATION - REMOVAL OF MINERAL DEPOSITS …..................... 327

12.2.1 Calibration for Acid Application ................................................... 328

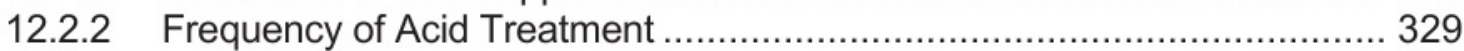

12.3 CHLORINATION - REMOVAL OF ORGANIC/BACTERIAL CLOGGING HAZARDS ........ 330

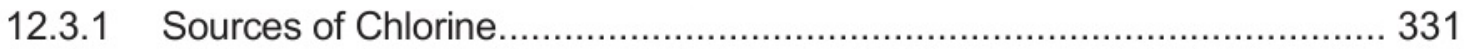

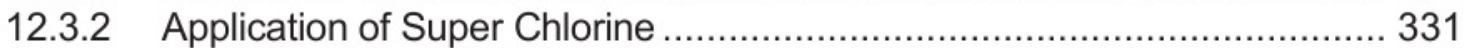

12.3.3 Procedure for application of Chlorination / Super Chlorination.................. 332

12.4 PRECAUTIONS FOR APPLYING ACID/CHLORINE ............................ 332

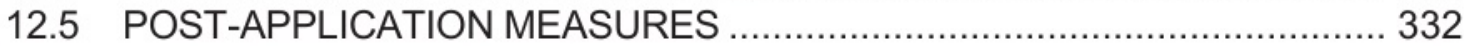

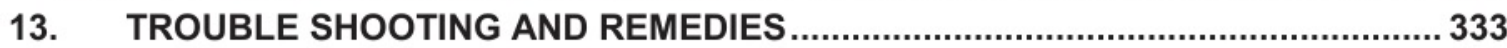

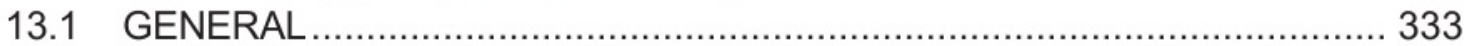




\section{INSTALLATION}

Installation of an irrigation system is very important and a crucial part that greatly affects the system performance.

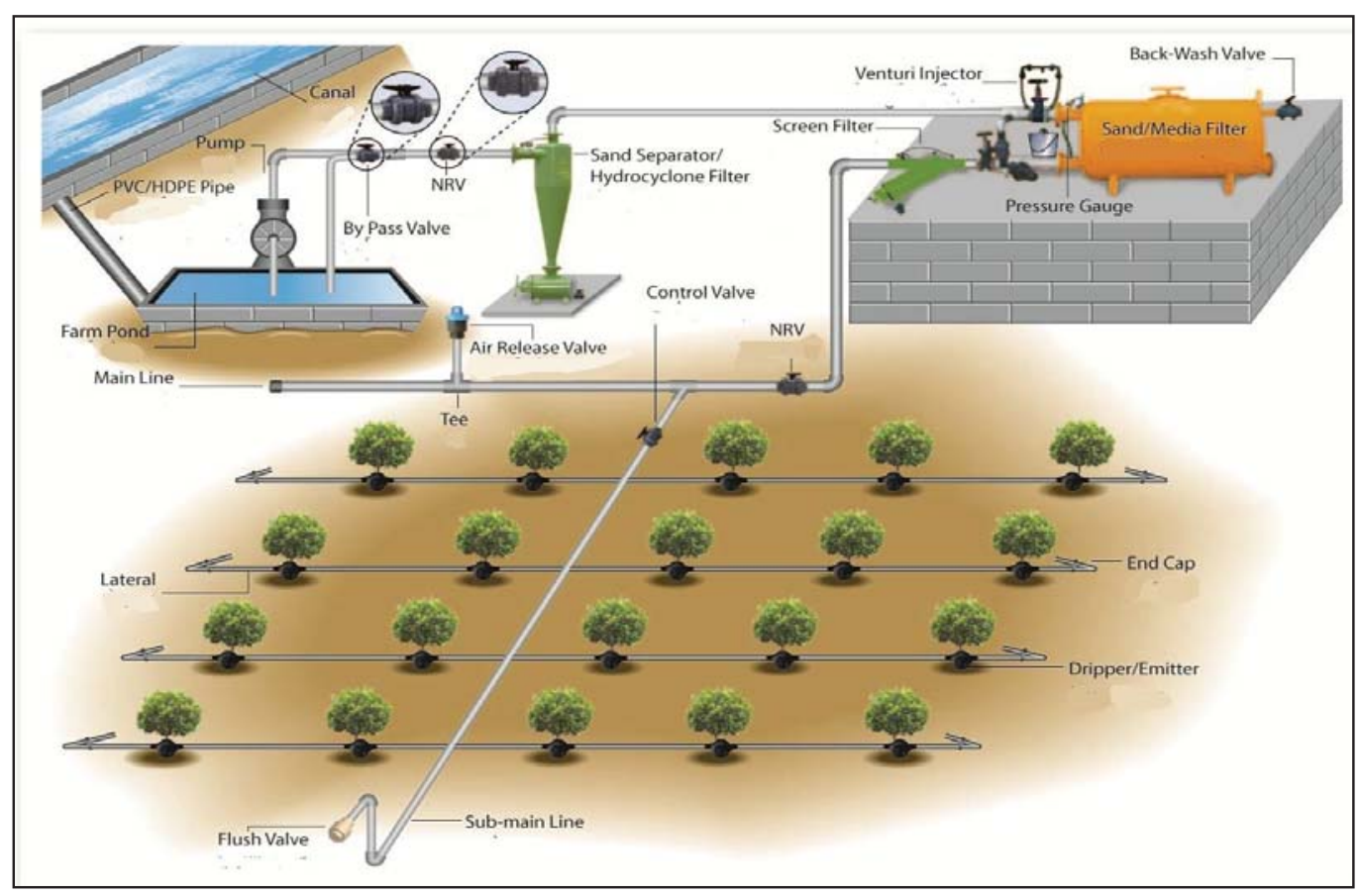

\subsection{INTERPRETATION OF DESIGN LAYOUT}

Design layout should be readable and self-explanatory so as field technicians may be able to install the system properly and accurately as per layout. For this, the technician must thoroughly check/study the layout and the legends on it and locate the different main and submain pipes on the layout. If the technician is unable to understand the layout, he, must then consult the site/design engineer to clarify the doubts in his mind. Subsequently, it should be checked that the physical situation on site are in accordance with that mentioned in the design layout. The installation of the system must be carried out strictly adhering to the design layout.

\subsection{INSTALLATION TOOLS AND ACCESSORIES}

The necessary tools required for installation of micro irrigation system include Pipe wrench, spanner set, drill machine, screwdriver \& pliers, cutting blade with frame, measuring tape, ejecto punch and sand paper etc. 

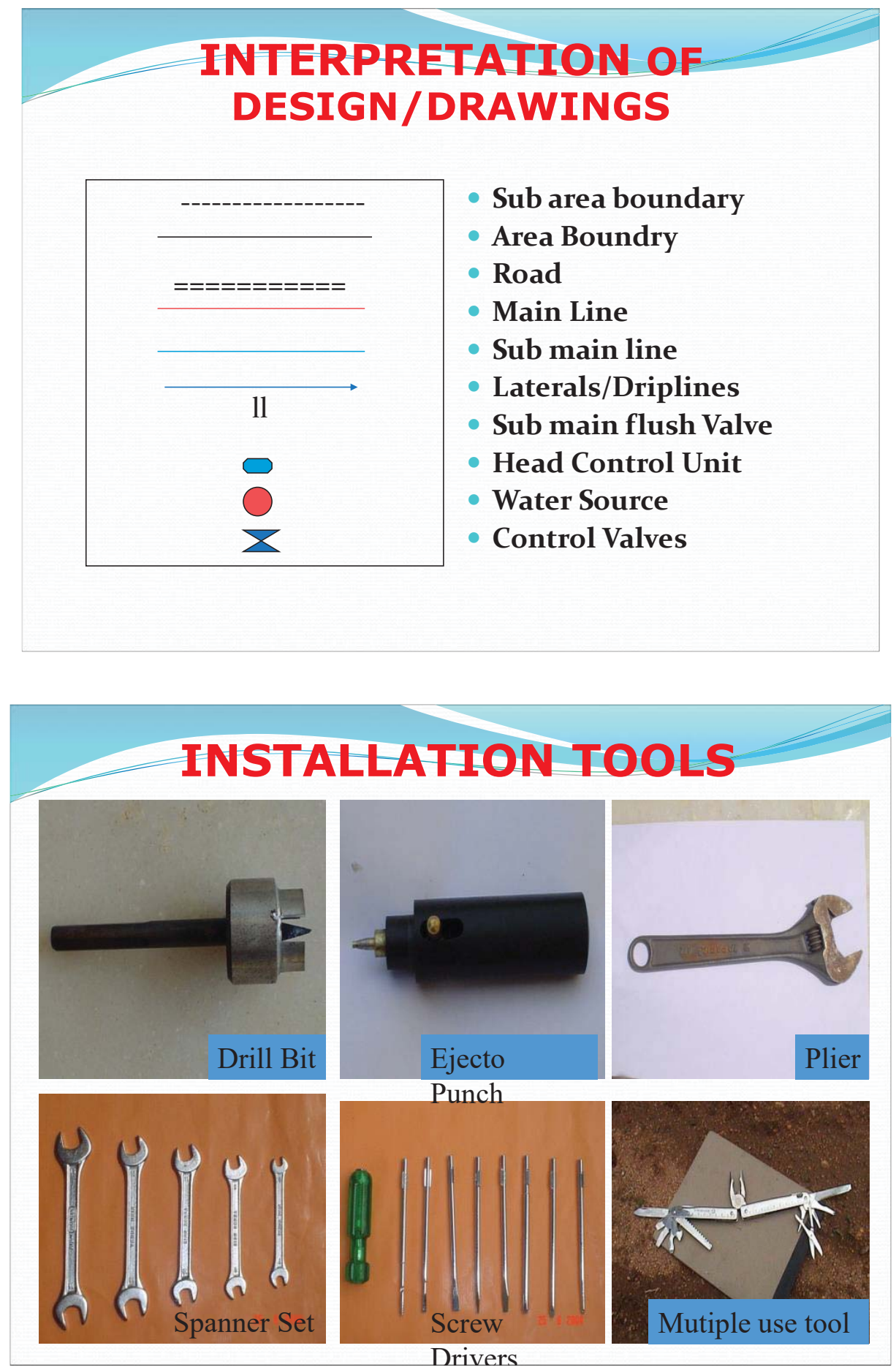

\subsection{HEAD UNIT INSTALLATION}

Fixing of head unit is the first step in installation of HEIS scheme. The installation follows with the construction of platform. The platform should be leveled and large enough to provide ampere space for hosting system component and necessary room for mixing fertilizers to be used in fertigation system. Pump set should be attached with platform via grouted bolts and connected with suction and delivery line as well as to the electric 
connection. Pressure gauges, flow meter and non-return valve should be installed as per manufacturer's recommendation.

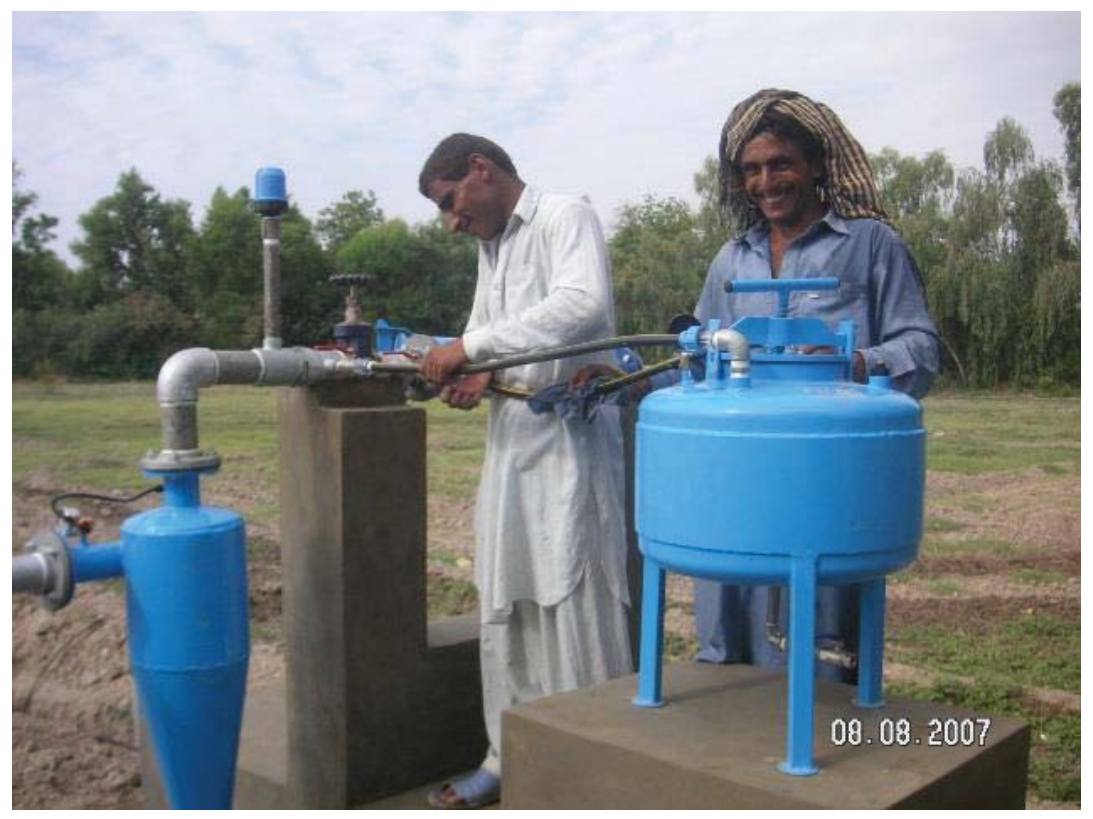

\subsection{TRENCHING}

Dimensions of trenches should be such that technician may have sufficient room for installation and jointing of pipes. Recommended trench dimensions should be $60-75 \mathrm{~cm}$ deep and $60 \mathrm{~cm}$ wide. The bottom of the trenches must be smooth, level and free of any sharp material such as stones or roots. A layer of river sand may be placed at the bottom of the trench in case of hard/rocky soil.

\subsection{LAYING PVC}

During the installation/lying of the PVC pipe following steps must be taken into account;

- Cut the pipe to length with a hacksaw or pipe cutter. Make your cut straight so the pipe is fully seated in the fitting.

- Smooth and level the edges slightly with a knife or fine file.

- Insert the pipe into the fitting and adjust to the correct position. Mark the pipe and fitting with a reference line to make it easy to find the position again after you have added the jointing solvent.

- Remove the pipe from the fitting.

- Clean the surfaces to be mated with a jointing solvent.

- Brush both the outside of the pipe and the inside of the fitting with jointing solvent.

- Push the pipe into the fitting with the marks 1/4 turn apart. Twist the pipe to align the marks. This spreads the solvent and makes a bead along the edge of the fitting. The bead should extend all the way around the pipe. Work quickly, the adhesive sets in 
about 30 seconds. If there occurs any mistake, separate the parts quickly. Once the joint is set, it's stuck for good.
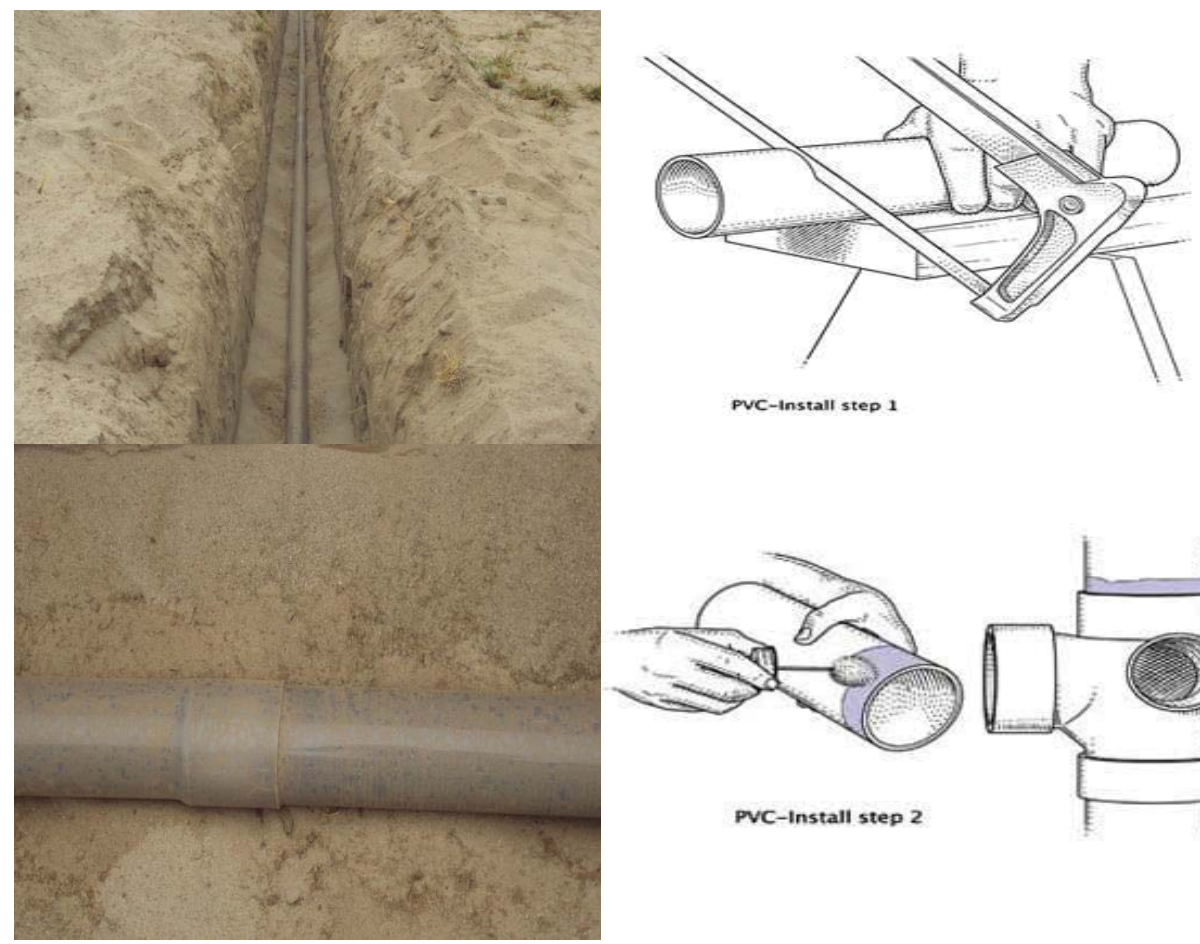

PVC-Install step
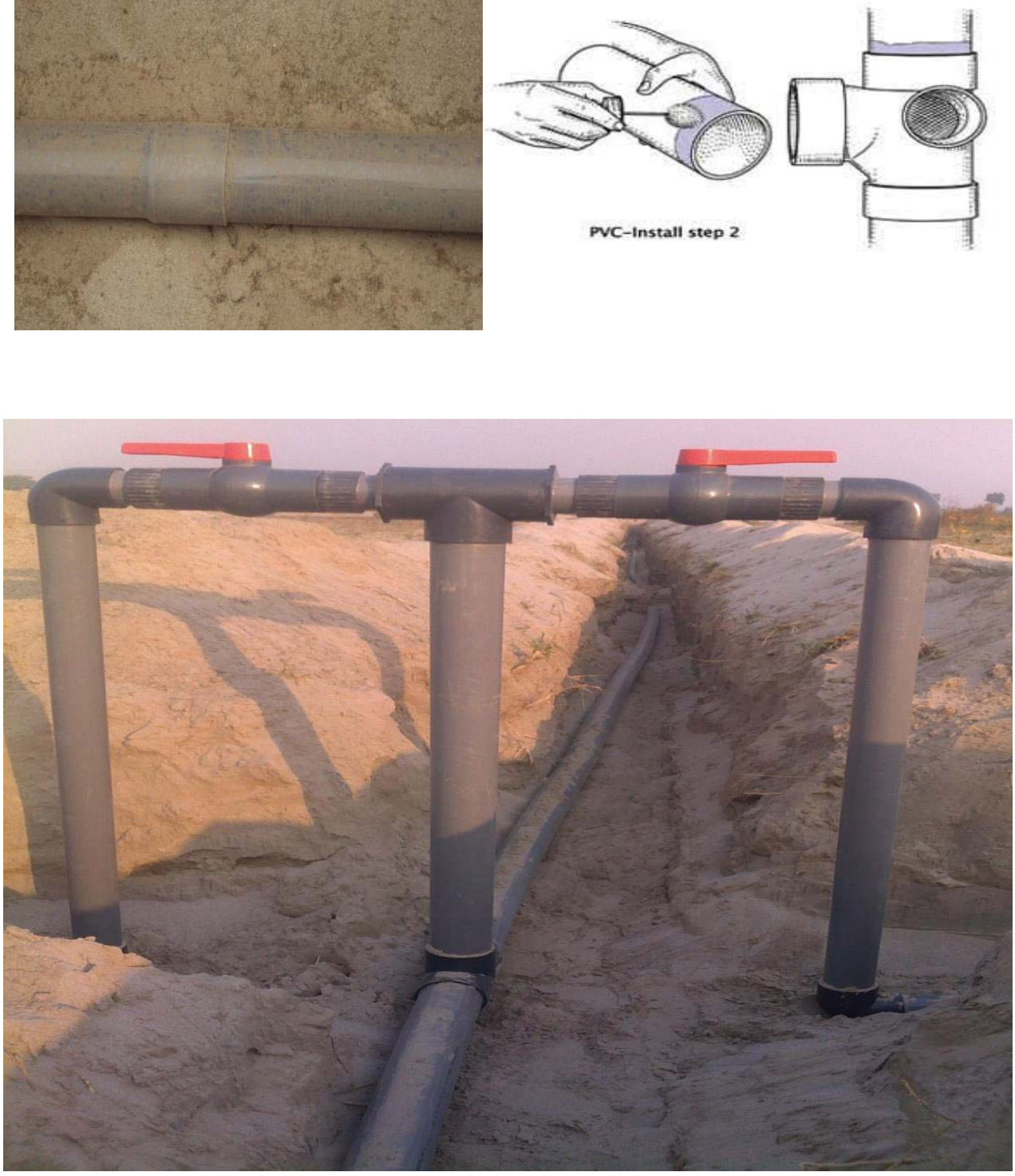

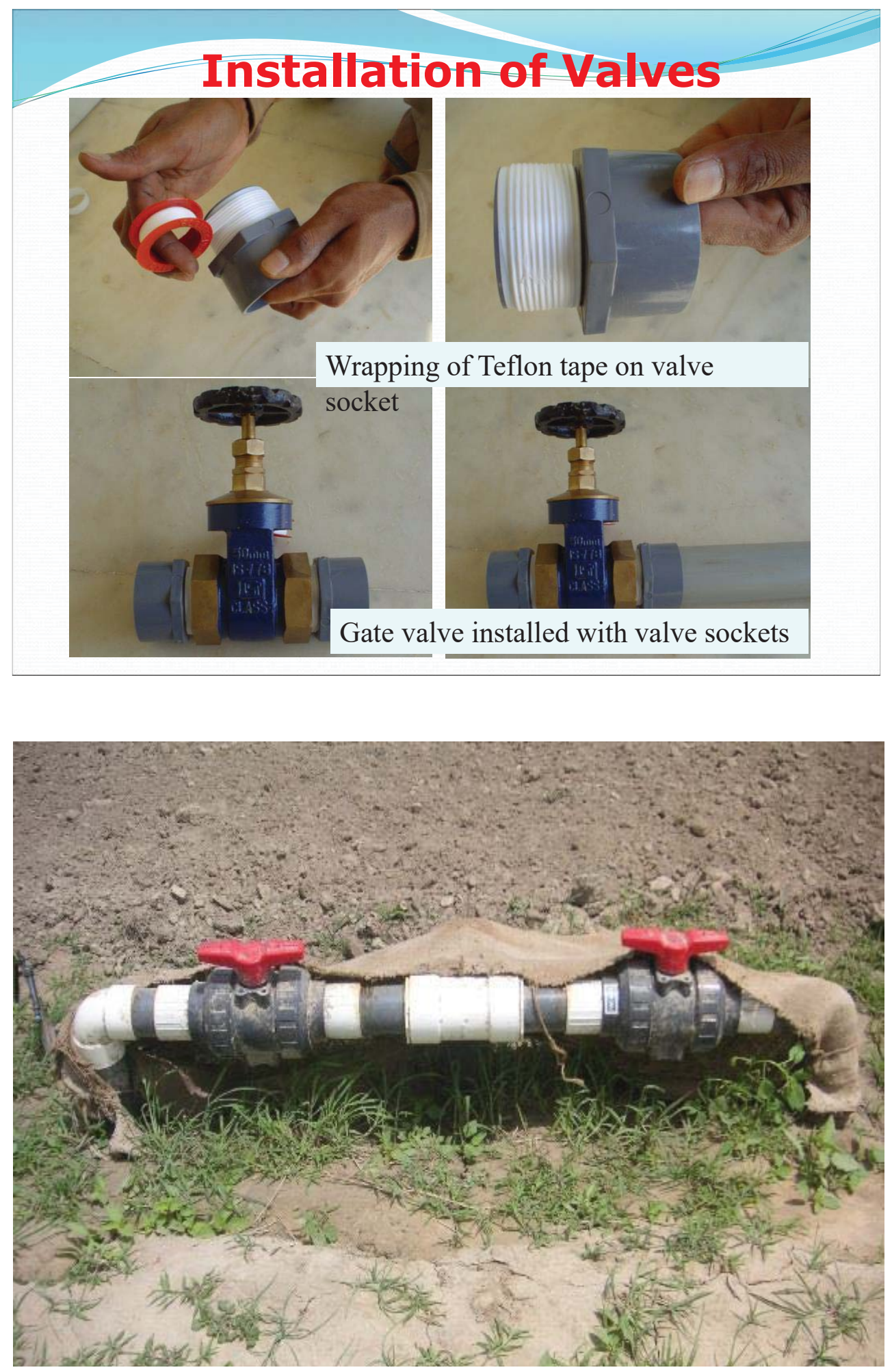

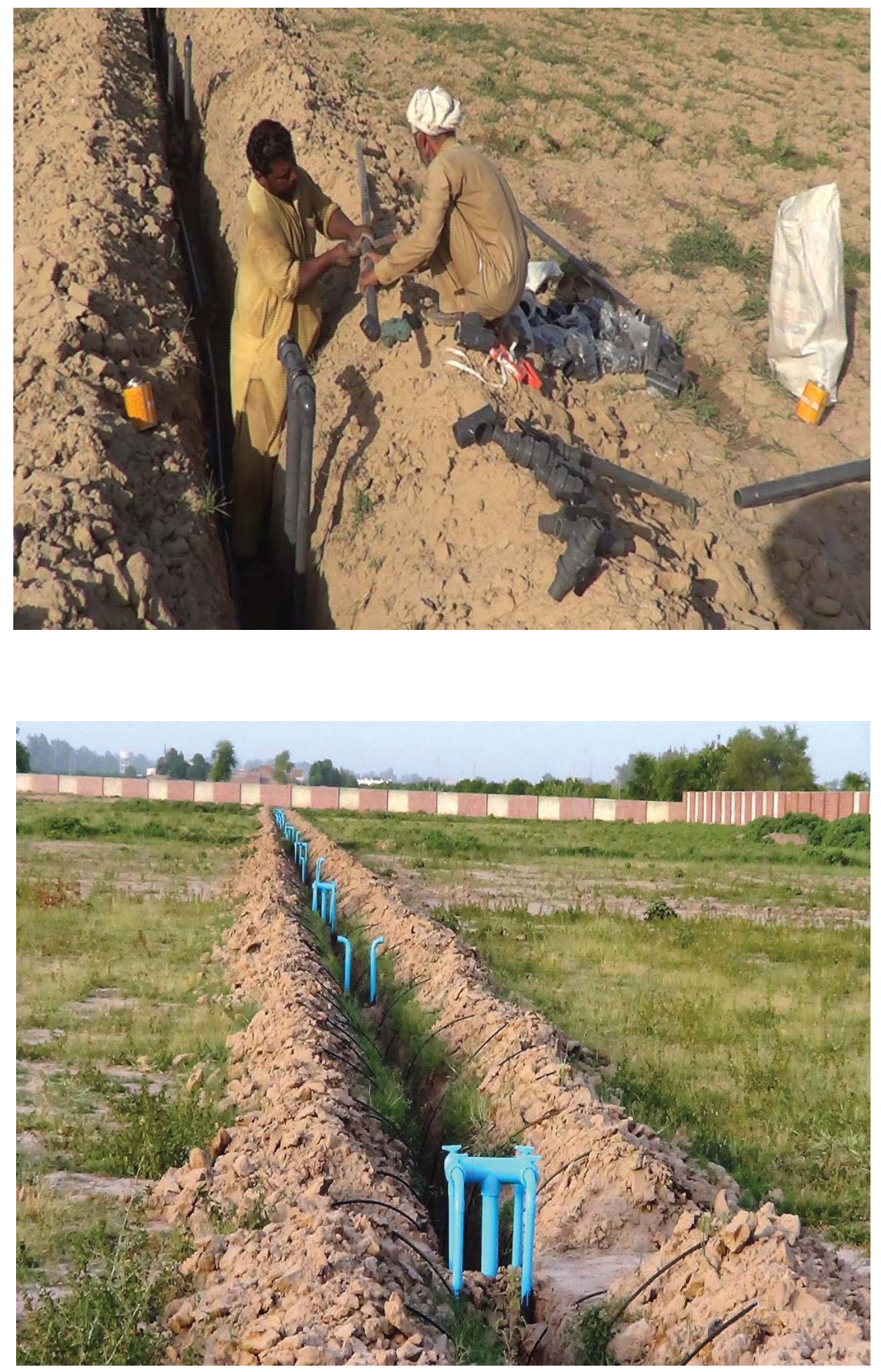


\subsection{LAYING LATERAL LINES}

Lateral should be laid as per design layout along the plant rows. Length of lateral should be cut about 3\% more to be turn and locking the lateral from the end. Care should be taken to lay the lateral line early in the morning or in the evening so as lateral length should not be cut short as it will be stretched in the sun. When cutting the lateral for inserting into submainline or to close the end, cut should be straight enough to control leakage.
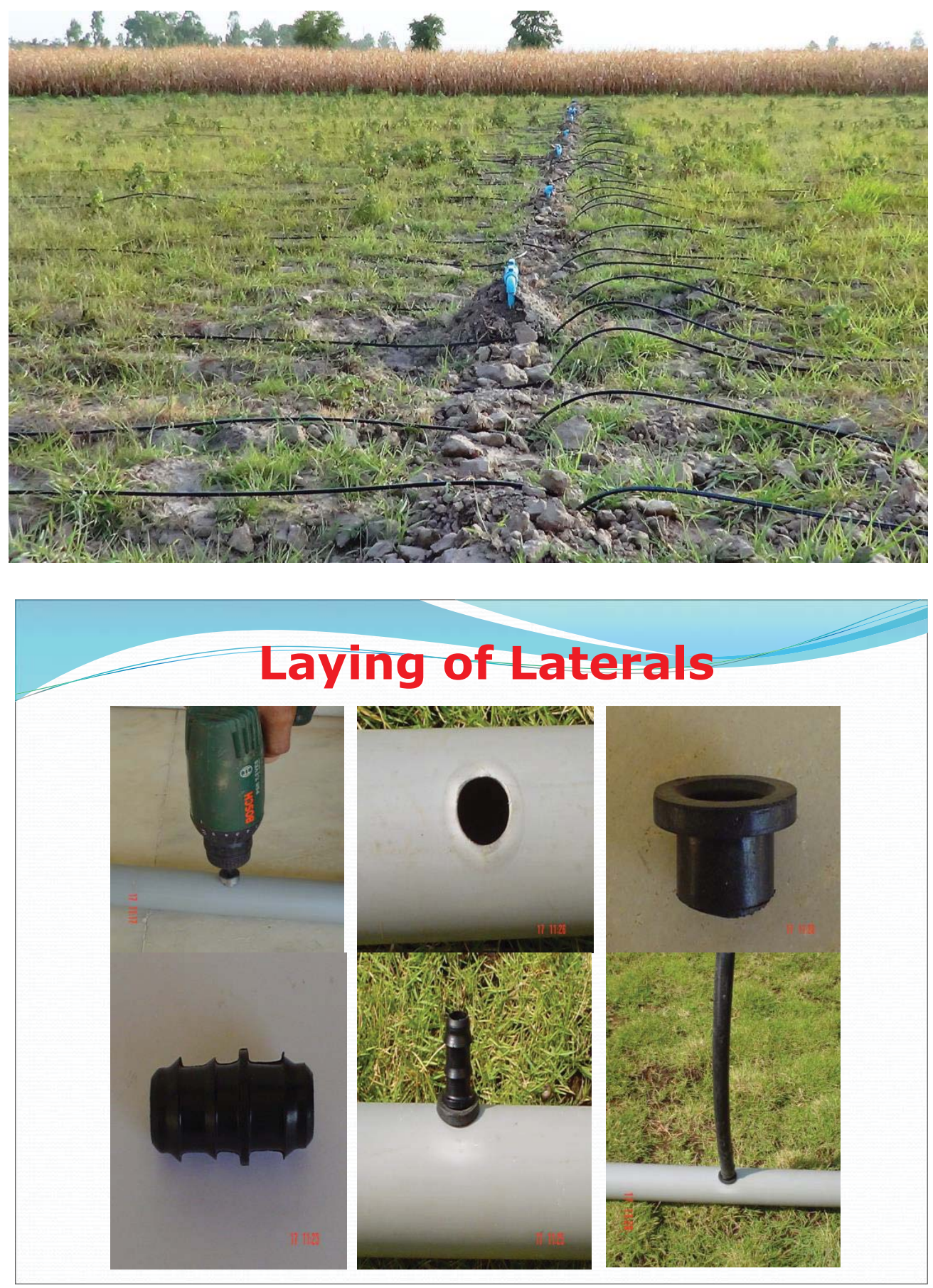


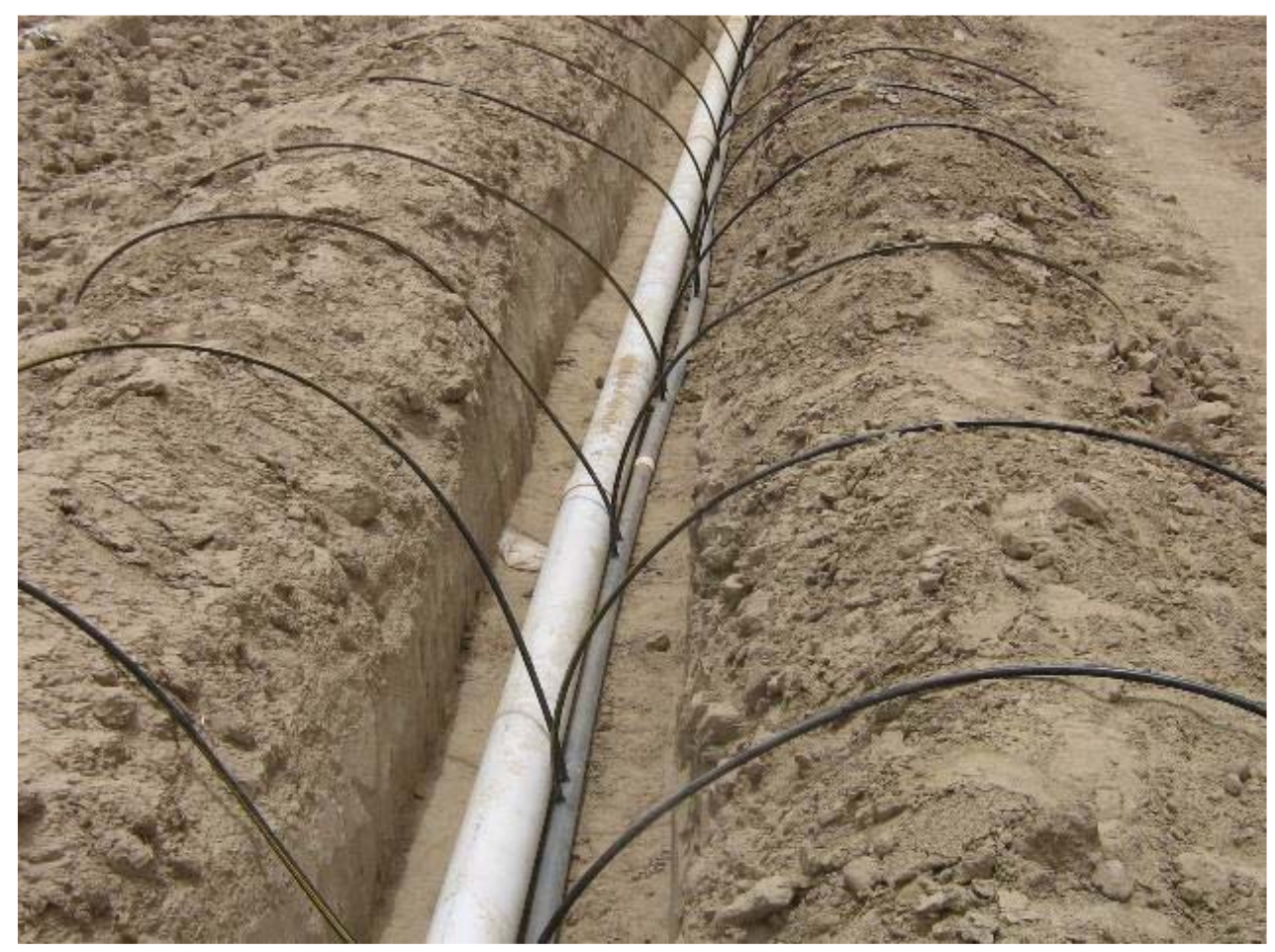

\subsection{PUNCHING AND INSERTING EMITTERS}

Always use the Ejecto Punch to make holes in the lateral line and care should be taken to install the dripper at required location. The distance between the emitters should be kept as per design. The residual punch material should not fall inside the lateral. Emitter should be inserted in the punched hole and the then pull out to fix it tightly

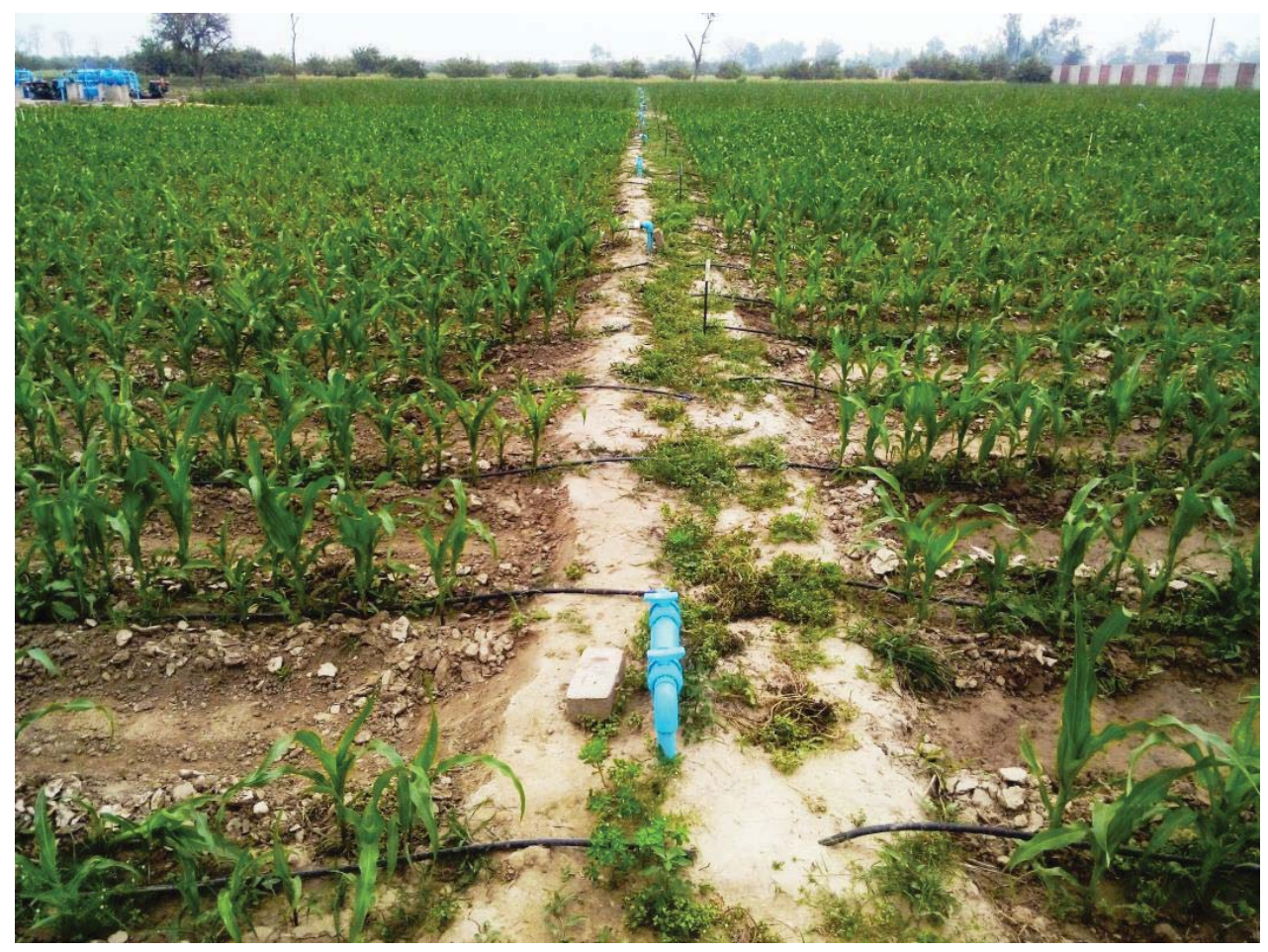




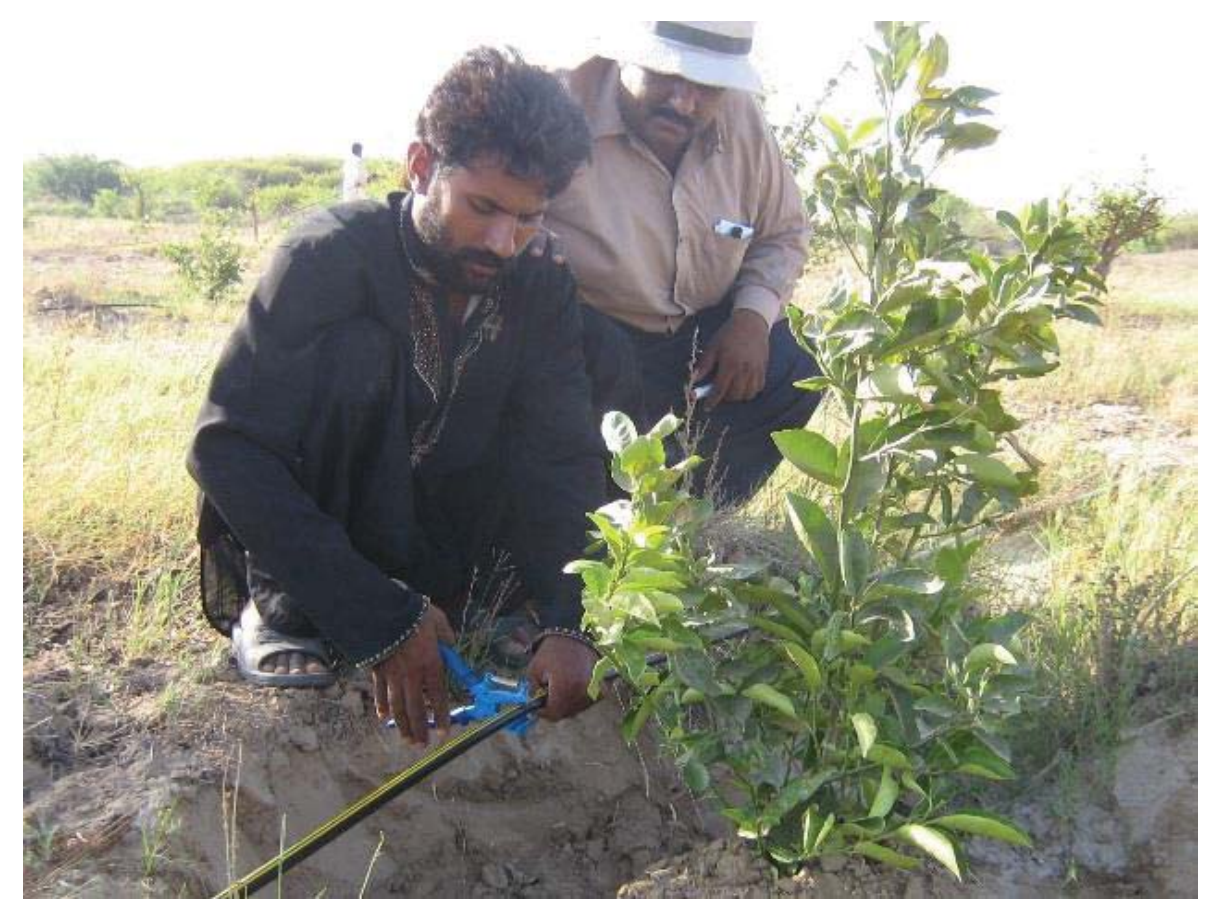

\subsection{BACK FILLING}

Backfilling is the process of refilling all trenches with soil again, covering all pipes, tubing and wires. Before you replace the dirt, screen the soil to remove large pieces. The dirt may contain rocks and other materials that can damage your pipes. Only fill the trenches half full, allow the water to move through the pipe line so that to assess any leakage or fault during installation. During the backfill with in roadways and side walk areas, all PVC pipe shall be bedded with crushed stone (less than $3 / 4^{-}$inch diameter) to 12 inches over crown of pipe. Remaining backfill shall be compacted thoroughly. Trenches shall not be backfilled until all required inspections and tests are performed. Backfill shall conform to the line and elevation of adjacent fields with no surface irregularities.

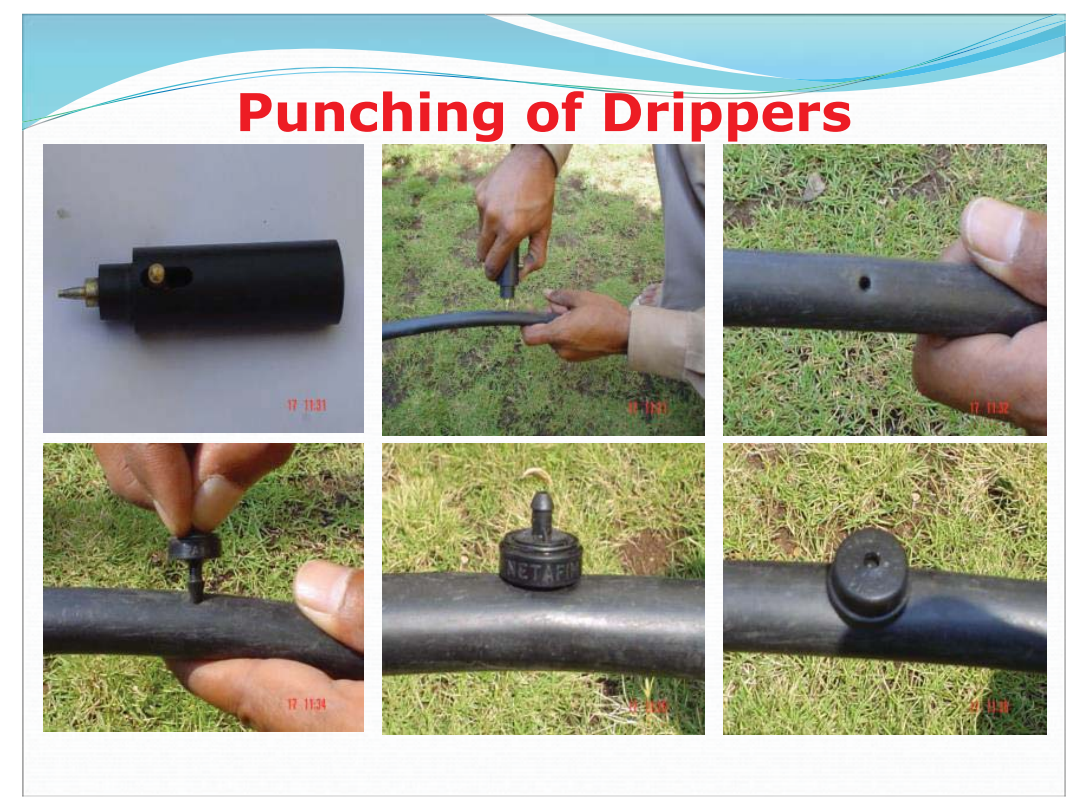




\subsection{TESTING AND COMMISSIONING}

- Check whether the installation is carried out as per the set guidelines and to the drawing

- The system should be tested before the final back filling of trenches

- Ensure all the control and flush valves of submains and lateral ends are open

- Start the pump and allow the pressure to become stable

- Ensure that there is no leakage at the joints in the sub \& main line and at the grommet take off

- Close submain flush valves

- Allow the lateral to completely flushed out, then close their ends with end cap

- Again check the submain and lateral for leakage

- Maintain the pressure at filters (1.5-2 bar at filter inlet), If excess pressure-open the bypass valve slowly

- Check the discharge of drippers randomly-use volumetric method

- Check working of ARV (provided at submain inlet) and submain pressure

- In case of Gravel filter as a primary filter, back flush the same and maintain adequate sand level

- Fertilizer tanks should be thoroughly cleaned. Use only $100 \%$ water soluble fertilizers

- Check for the pressure at lateral end. Always maintain minimum 1 bar pressure at lateral end for proper discharge through emitters and minimize clogging chances.

- Always run the system with proper pressure to get maximum life / benefit of it.

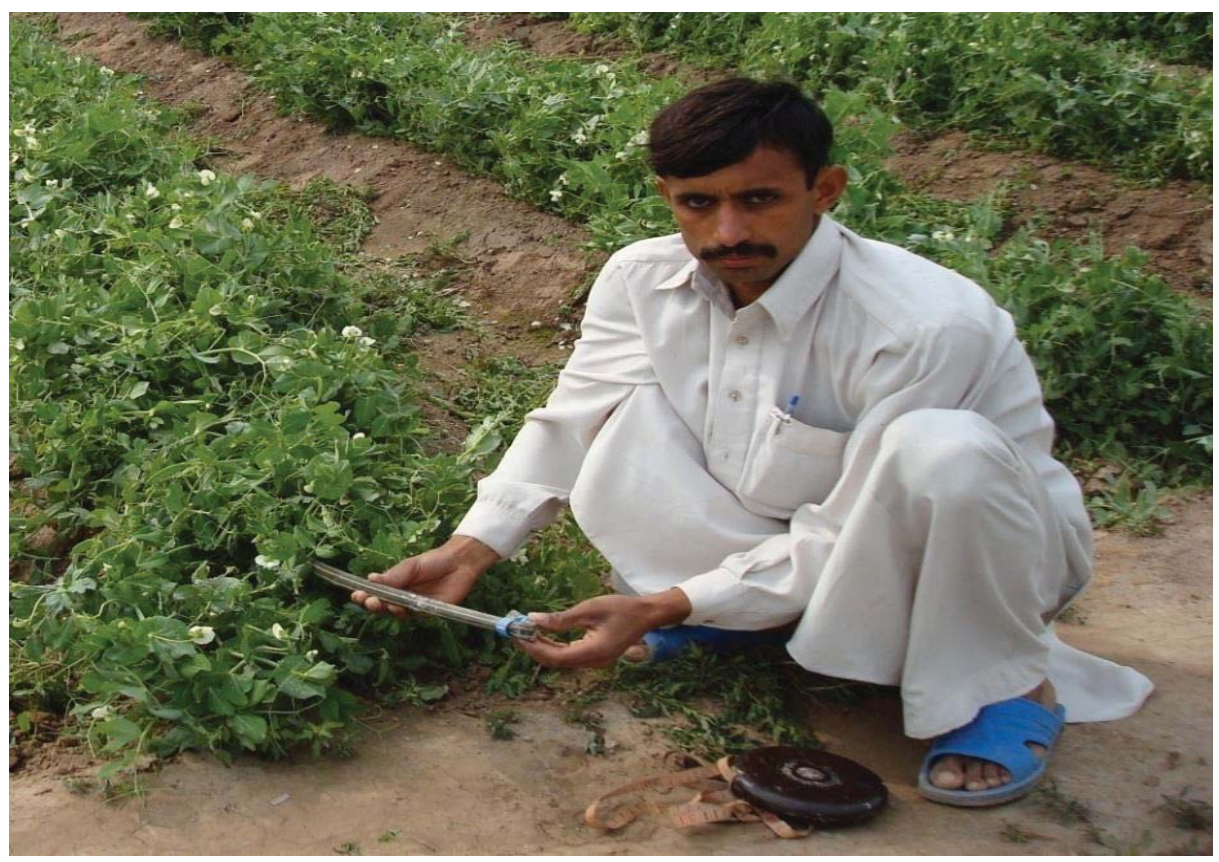



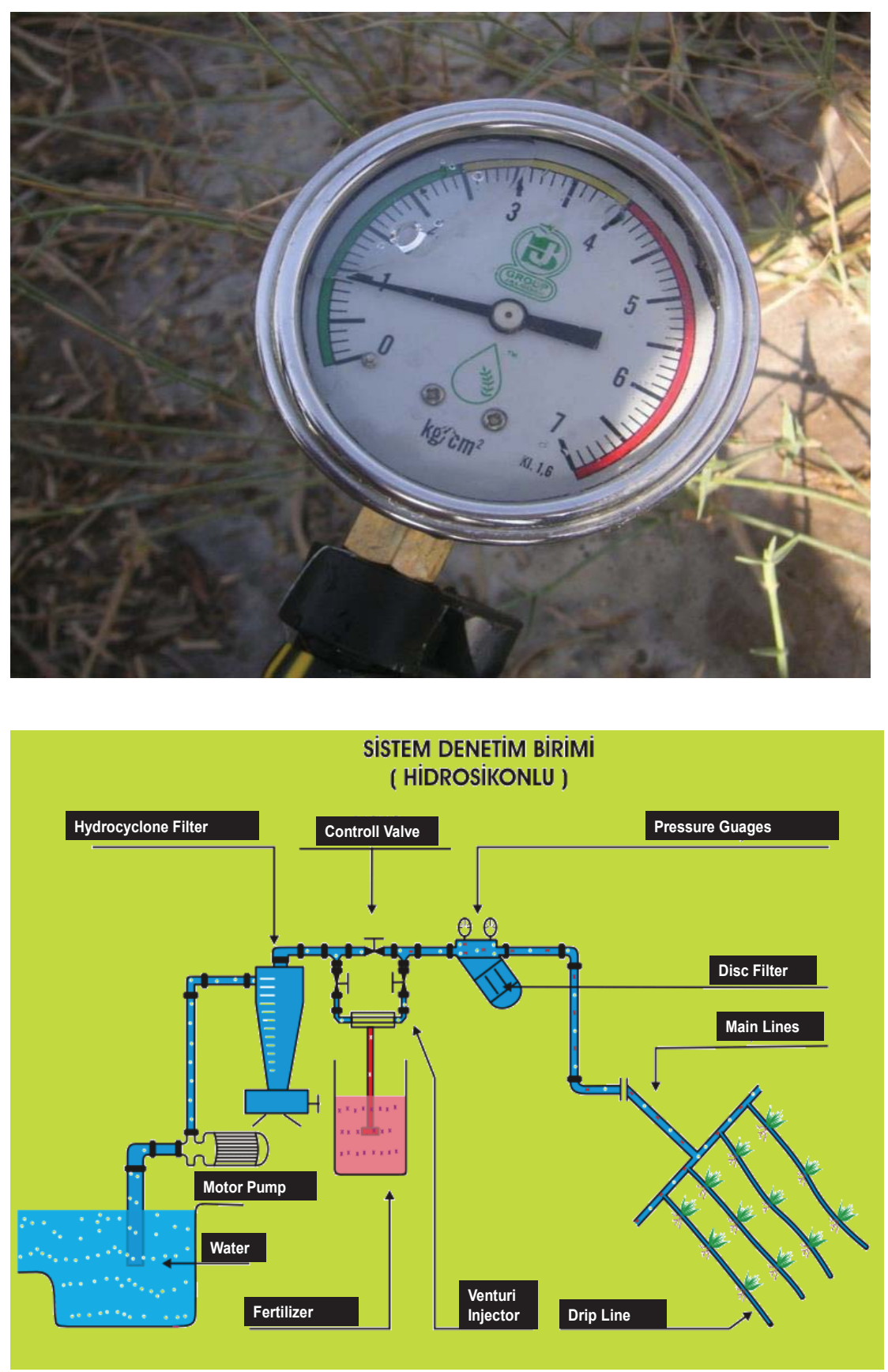

\section{Measurement of Emitter Discharge}

- Several cans were placed at different locations along the laterals in the field

- 15 minutes after the operation of the system, reading were taken of emitter discharges

- While taking discharge readings one bar pressure was maintained at the end of every lateral

- The pressure at the end of the lateral was 1 bar 


\begin{tabular}{|c|c|c|c|}
\hline Cane No. & Volume (ml) & Time (minutes) & Discharge(lit/hr) \\
\hline 1 & 348 & 5.21 & 4 \\
\hline 2 & 347 & 5.21 & 4 \\
\hline 3 & 348 & 5.21 & 4 \\
\hline 4 & 347 & 5.21 & 4 \\
\hline
\end{tabular}

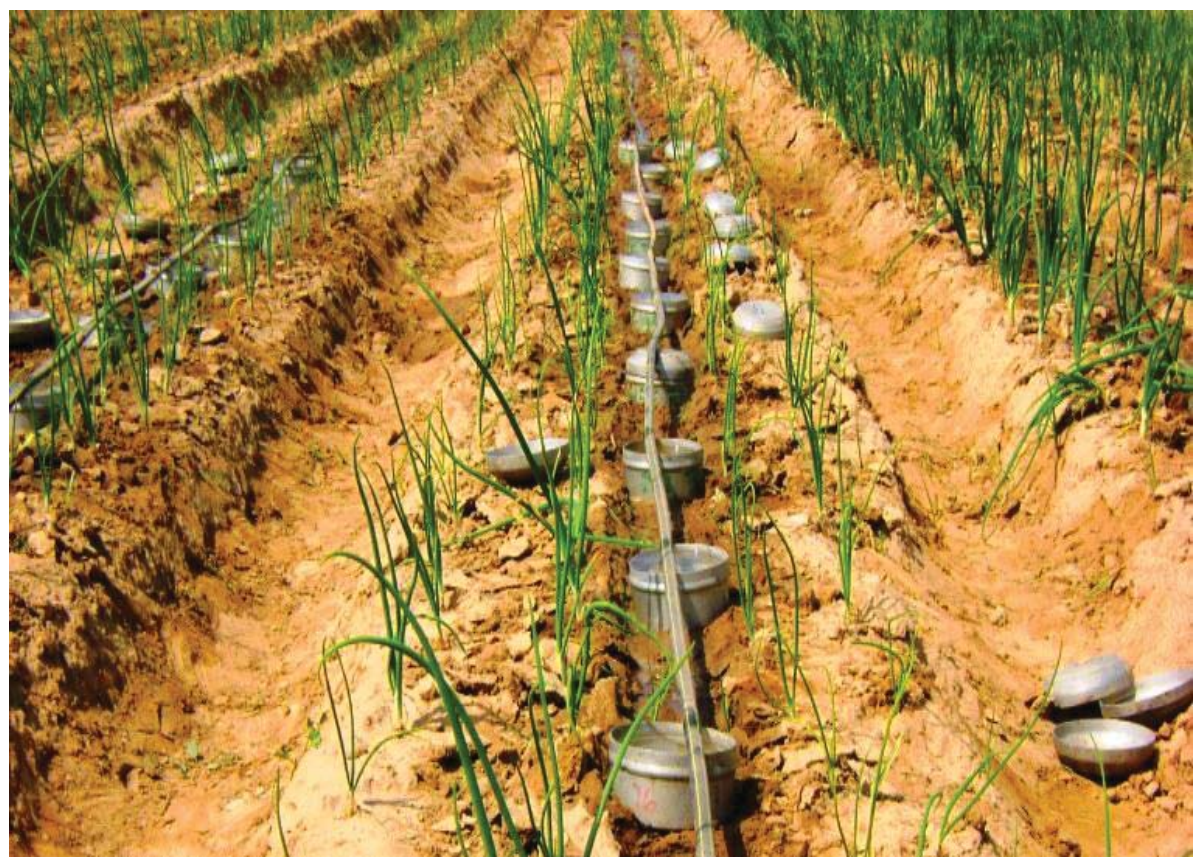




\section{OPERATION AND MAINTENANCE}

\subsection{GENERAL}

Operation and maintenance of drip or sprinkler irrigation system are most critical factors that decide success or failure of these high efficiency systems. Poorly designed system with low quality material requires more frequent maintenance whereas a well-designed system with a good quality of material synchronized as per design may needs maintenance very rarely. Maintenance of the system also depends upon the operation time. If a system operates for more hours and more frequently, it must require a more maintenance. Furthermore, maintenance costs to be borne on the system may be reduced by proper handling and care. It depends upon the vigilance and handling behavior of the operators/farmers as well. It is therefore a matter of prime importance to operate a system carefully and maintain regularly. Operation and maintenance requirement of drip/sprinkler irrigation systems are govern by the following aspects:

- Acquiring complete information and instruction from designer (pump capacity, rpm, designed flow in different blocks)

- Determine when and how long to irrigate (crop water requirement, stage and climate wise)

- Checking the water meter reading and record the figure

- Accurately setting the hydraulic valves

- Beginning with pressure readings at the head and ensuring the air release from air release valves

- Checking the working of prime mover and pump

- Checking the leakages in power and field unit otherwise the operating pressure will disturb

- Checking the emitters, at least on a random basis

- Setting the chemical and fertilizer injection equipment

- Handling and care during and after use

- Quality of water being used

- Selection of filters

- General behavior of operator

- Maintenance Routine

\subsection{MAINTENANCE PRINCIPLES}

Some principles if followed in the operation of high efficiency irrigation systems, various minor and major wear and tears of the system and cost on the repair and replacement can be saved to large extent. These practices/principles can also save the operator and a farmer from unduer operational problems during the cropping season and ensure continuous application of water as per irrigation schedule to meet the crop water requirements. Few principles that can be observed for operating a drip/sprinkler system are delineated hereunder.

- Determine the problem timely

- Respond immediately to the problem 
- Need based solution to the problem

- Availability of spare parts

- Vigilance of system components during operation

- Estimation of maintenance requirement

- Development of maintenance plan prior to season

\subsection{GENERAL MAINTENANCE TIPS}

Drip/Sprinkler irrigation systems requires very frequent maintenance on daily, weekly, monthly and seasonal basis. Maintenance tips if done regularly prior, during and after the operation of systems prove very useful in smooth running of the system without any unnecessary breakdowns. Some general maintenance tips are being listed below that may help in keeping the system trouble free for most of the times.

- Spare Parts of commonly required items should be kept at farm in secure place to protect them from rodents, theft and sunlight.

- Filter, Emitting Devices, Lines, Couplers and Connector should be checked most frequently as these are more sensitive parts of the system that require routine maintenance.

- Any leakage, blockage, and pressure variation should never be left unattended

- Regular maintenance of equipment will reduce repairing costs, increase the system life and reduce the risks of any unnecessary interrupting during irrigation cycle.

- Carry-out regular and frequent filtration until the best cleaning/back flushing and washing schedule for the system is determined.

- Fluctuation in the operating pressure against the working/designed pressure is always an indication of some problem e.g. leakage, clogging or blockage in any of the system component.

- Always follow the instructions and guidelines given in the user's manual provided by the supply company.

- Always consult with the specialists, if problems cannot be easily handled by the farmer/operator.

- Maintain the system even it is not in operation for a longer period of time, remove easily detachable components (e.g. Laterals) from the system and keep them in a safe place. 


\subsection{CHECKING PRIOR TO STARTING (DAILY CHECKS)}

General checking prior to running a system will take only few minutes but can save from many possible faults in the system. It is very important to check the following system components before running a system as a routine.

- Water in the Water Storage Tank (if system has been installed on WST)

- Voltage on the electric penal (if power source is electricity) and diesel in the engine (if power source is diesel engine) to ensure that sufficient quantity of diesel is available to complete irrigation cycle for the day).

- Inlet and out-let valves (these should be open)

- Status of the filter(s), flush once immediately after running the system

- Valves connecting water supply line to fertilizer tanks are closed.

- Gauges on the system: immediately after running systems to check that system is running at designed/working pressure.

- Main delivery line is intact.

- Fertilizers are available, if fertilizer is to be injected during the irrigation cycle.

\subsection{CHECKING OF PUMPING SYSTEM}

\section{Before Operation}

- Check fuel, oil and water levels in diesel engines.

- Check fertilizer tanks for correct type of fertilizer and adequate quantity.

- Check fertilizer pump's) for proper functioning

- Check valves for proper functioning.

- Make sure all filters are clean.

- Check chlorination equipment

\section{During Startup}

- Verify that the pumps are functioning properly.

- Watch for unusual noises, vibrations and overheating that may develop in the pump drive due to pump malfunction

\section{After Startup}

- Check pressure and flow rate at pump outlets

- Check fertilizer and/or chlorine injection; check dosage.

- Check downstream filter pressure and make sure that pressure loss is within the acceptable limits.

- Check the system visually for bursts

- Select critical points in the irrigation system and measure the pressure at those points

The maintenance of pumps and drive units includes their proper lubrication, in accordance with the manufacturer's recommendations. Maintenance also includes: periodic adjustment of the impeller clearance in turbine pumps, tightening of packing glands in centrifugal pumps, periodic adjustment of the engines for improving their efficiency, and frequent inspection of the proper pump operation 


\subsection{OPERATIONAL PERIOD}

Some crops love to be irrigated during the days, some during the nights or in the evenings or mornings. A farmer/operator should have understanding of the crop water requirements in respect to the period of irrigation during irrigation cycle. He can also consult the Agronomist for deciding timing of starting and ending of irrigation cycles as per crop needs. Similarly, during and immediately after the rainfall there may not be any need to run the systems as water requirements of the crop has already been met through the rain. Heavy rain falls can, however, leach down the nutrients from the root-zone. In this case, sometime operators have to apply light irrigation just for fertigation to replenish nutrient status of the soil as per plant requirements. Likewise, during the spells of frost crop may require light irrigation only to protect the crop from frost injury.

System must be operated only during those hours when operator can remain near the system to check possible breakdowns and to carry out flushing of filters whenever required. Operator has to remain vigilant to observe prevailing weather condition or he can simply follow the recommendations of the Metrological department for occurrence of rain or frost and taking necessary measures. Some insects also attract towards the emitting places/near the plants if system is being operated during the hot days in search of comfort places or water. This situation may increase the insect attack to the crop/plants. Running the systems during nights may help in overcoming such kind of situations.

\subsection{OPERATIONAL DURATION}

Operational Hours of the system mainly depends upon the daily crop water requirements. At peak requirement periods system has to be operated for longer hours whereas system needs to be run for a shorter period of time during lean crop water requirements periods. It is highly important to ensure in advance that system will run satisfactory especially if peak requirement period is approaching because during this period operator may not have ample time for repairs as system will run for longer hours and intermittent period for system maintenance will be very short between two irrigation cycles. Spar e $p$ ats for th e components need more frequent replacements (e.g. drippers) should be made available particularly before the start of peak period.

\subsection{VIGILANCE AND CHECKING DURING SYSTEM OPERATION}

Any reluctance from the operator during running a system may lead to the faults of serious nature and long unnecessary breaks between irrigations. Operator must remain vigilant and frequently check the pressure gauges which are the main indicators of faults, if there is any. Operator must also check the situation in the field that all drip lines are running without leakage/chocking and drippers are running without any blockage. It is needed to ascertain application/distribution uniformity. 


\subsubsection{Water Flow Rate and Flow-Meter Observations}

Water Flow Rates should match the flows/discharge given in the design of the systems to meet Crop Water Requirements. Flow from the system to mainline may be confirmed by reading from the flow-meter which gives reading in liters or cubic meters. The volume of water applied can be calculated by multiplying the flow with operation hours.

\subsubsection{Checking of Pressure Gauges and System Flushing}

It is very important to keep an eye on the pressure gauges at frequent intervals during system operation. Increase in the pressure on the inlet pressure gauges tells the operator that there are some blockages in the filters and cleaning/flushing/back washing is needed. Similarly, increase in the pressure at the out let gauges shows that flow rate have been increased than the designed flow rate. It happens when mesh in the filter has been busted and required replacement. Pressure gauge at the inlet point of the main line shows pressure variation in the mainline that indicates blockage in the line if pressure has increased and indicates busting or heavy leakage at some point in the line if pressure has suddenly dropped. Hence, it can be stated that pressure gauges provide early warning from the potential damage to the systems and therefore must be monitored while operating a system.

After having experience of running a system for quite some time operators can learn that how often he has to back flush his filter and flush system lines that mainly depend upon the water quality and capacity of the filters. By knowing the flushing requirement in general, operator must perform flushing of filters/system at specific intervals without waiting for increasing the systems pressure at pressure gauges. This practice may save the operators and system for any potential hassle and breakdowns during operation. Addition of automated valves at drainage outlets of filters however can provide flexibility and ease to the operator besides better safety of the system.

CARE: Cover the gauges with polyethylene bags to protect them from entering of moisture and rain water.

\section{Daily Maintenance}

- Start the pump and allow pressure to become stable

- Open the drain valves of hydrocyclone and screen filters

- Back wash the sand media filter

Open the back wash valve

Close the outlet valve

Open the by pass valve

Close the inlet valve

- Operate by pass valve to maintain pressure in the system

- Visit the field to rectify leakage/damage, if any 
- As irrigation over, check the wetting patterns

- Remove the end caps of laterals (4-5) and flush for 1-2 minutes and also check impurities

- Flush the submain to remove debris

\section{Fortnightly Maintenance}

- Check the inlet \& outlet pressure difference of sand media filter $(<=0.5 \mathrm{bar} / 5 \mathrm{~m}$ of water)

- Due to deposition of salts the top surface of bed becomes hard and back washing is not effective

$\checkmark$ Open the lid of filter

$\checkmark$ Adjust the flow using bypass valve so that sand does not come out of the opening

$\checkmark$ Allow water to come out through lid openings

$\checkmark$ Stir the sand from top to bottom carefully

$\checkmark$ Break the lumps of sand by squeezing in hand

$\checkmark$ Ensure the sand up to marked level

$\checkmark$ Allow the water to flow till clean water starts flowing out of opening

$\checkmark$ Put the lid back in position tightly

\section{Monthly Maintenance}

- Deposition of fine particles and sand on filtering element of screen filter

$\checkmark$ Open the lid of and take out the filtering element

$\checkmark$ Remove the rubber seals from both ends, clean and fix them again

$\checkmark$ Rinse the element in flowing water gently with hand

$\checkmark$ Do not use wired brush, as it may damage the screen

\section{Half Yearly Maintenance}

$\checkmark$ Change the sand of media filter with new one as particles becomes rounded off

$\checkmark$ Check out system wear and tear

$\checkmark$ Lubricate the pump and motor

\section{Lateral Protection from Rats}

$\checkmark$ Always maintain wetted strip in the field (Row Crops)

$\checkmark$ Burry (3-4" below ground) the lateral between two drippers (Orchards)

$\checkmark$ Place bowls of water at different locations in the field for squirrels

$\checkmark$ Wrap plastic/polyethylene sheet around the trunk of trees to stop climbing of squirrels

- Start "Rat destroy campaign" in the area by all farmers

\subsubsection{Maintenance of Mains and Sub-Mains}

Mainline and sub-main lines are parts of the systems that need least repair and maintenance if the same have been coupled/connected correctly at the time of installation. It is very important to fill concrete at the turning/end point that will save the breakage/leakage of the lines at these points which are the weakest points in the lines and thus more prone to the damage. The other part of the mainline most vulnerable to leakage/breakage is the point where it joints with the head unit. The coupling point of the mainline with the system may 
breaks if head unit has not been assembled properly and creates vibration on running. If leakage or breaking occurs at this joints systems should be turned off to fixed damage immediately.

Farmers should keep the tightening clumps near the system to tighten the mainline with the system, if leakage/breakage occurs. Leakage during fertigation, chemigation should not happen as it may lead to the fatal damage to the system or injury to the operator. It may also cause a financial damage to the farmers due to wastage of expensive agrochemical being run through the system. Mainline should be flushed weekly or monthly to remove any blockage in the mainline. As mainline remain buried under the ground and it damages very occasionally through physical means. If damage occurs, it is wiser to change the affected length complete than repairing the line with other means. If there is a damage of serious nature and it damage occurs again and again then assistance from the specialist must be requested. It is, however, very difficult to find the damage in the buried main/sub main lines especially if the leakages are of minor nature.

\subsubsection{Checking and Maintenance of laterals and emitting devices}

Damage or leakage of the lateral and emitting devices (drippers, mini/micro sprinklers etc.) can be identified simply by visual inspection. Damages of the lateral can be fixed easily by replacing the damaged portion of the lateral and attaching new portions with the help of joiners. If clogging occurs in the emitting devices it may be removed by opening and

\section{Causes of Damage}

1. Physical damage caused by rodents (rats, porcupines, squirrels etc.) or by the animal trespass.

2. Damage caused by intercultural operations.

3. Roots and plants growing through the line/drip tape

4. Entry of the roots into the drippers

5. Poor water quality and inappropriate Chemigation

6. Mishandling and mismanagement

cleaning the device. Sometimes just tipping the device may remove the clogging. Frequent acidification and chemigation may also be needed to control clogging and frequency of the practice depends upon the water quality passing through the emitters. The dripper should not, however, be removed from the lateral line for cleaning. Farmer should maintain its inventory of spare parts and emitter in sufficient numbers for replacements in case of complete clogging/damage. During inspection of lateral lines and emitting devices it is necessary to position the displaced line and emitters. Sometimes clogging occurs if the drippers suck back the soil or water ponding on advent of rain. Drippers with caps on the outlets or their placement in the upward direction on the laterals are recommended to overcome such problems. The major causes of damages to the laterals and emitters and there remedies have been highlighted in the following boxes. 


\section{Remedies to Prevent Damage}

1. Rodents puncture the drip line/tape for search of water or cool place during hot days. Placing a water at different location can prevent the laterals from potential damage

2. Burying of lateral line 3-4 inches below the ground in-between the emitters can save it from damage by the rodents

3. careful intercultural operations with trained labour can avoid the physical damage to the drip lines

4. The problem of poor water quality can be handled by acidification/chemigation to minimize clogging.

\subsubsection{Operating and Cultural Practices}

Converting surface irrigation system to a more efficient High Efficiency Irrigation System (Drip/Sprinkler) demand a major shift in the cultural practices in terms of selection of crop, preparation of land, sowing techniques, planting geometry (Row $x$ Row and Plant $x$ Plant spacing), pest and disease management, weed control, harvesting etc. By adopting drip irrigation system farmers have to grow their crops in rows for which it is very necessary to design crop planting systems in accordance with the plant cover area at maturity and lateral to lateral distance as per design. For instance, if system has designed for sugarcane and farmer wants to grow cotton on it in the next season, farmers may have to grow four rows of cotton instead of two rows of sugarcane (grown previously). By making this shift farmers must have the knowledge of Crop Water Requirement (CWR) and crop inflorescence. If not, farmers may take advice from the agronomist to make any such shift. Farmers have to make some changes in land preparation as and he has to decide that crop will be grown on the beds or flat lands. It is recommended that crop sensitive to high moisture contents must be grown on the beds (e.g. cotton, potato, strawberry) and crops comparatively less sensitive to high moisture contents may be grown on flat lands (maize, sugarcane, sunflower etc.). On the soils having high salts contents, it is recommended that place lateral/emitter near the tree trunks/crop so that when water is applied to the crop it travels from inside to out rather than outside to inside, incase laterals have been placed little far from the trees/crops. Placement of the laterals is also important on the beds or in between the beds keeping in view the crops water requirements at different stages. For example, farmers sometimes place lateral in between the beds before germination of the seeds when seed may rotten due to excessive moisture. The same lateral will be moved on the beds when crop water demands increases.

\subsubsection{System Operation and Inter-culture}

Drip Irrigation Systems once installed and laterals are laid down in the field, it is very difficult to practice intercultural operations such as hoeing, ploughing, spraying etc. It also restricts the movement of farm machinery freely in the field. Such limitations demand shift in the 
intercultural practices that should match with the new planting geometry (mostly in rows) and system layout in the field. Farmers some time require to make changes of minor nature to its farm implements. Hand hoeing is not recommended as little carelessness during the operation may cause severe damages to the system lines. It is very important to use only trained labor for intercultural practices.

As far as inter-culture under sprinkler and center pivot systems are concerned, it provides some flexibility and does not create any hindrance to the farm machinery and implements. The only limitation with these systems is excessive wetting of the soil that does not allow intercultural operations cannot be carried out immediately after the irrigation.

\subsubsection{Care after Completing an Irrigation Cycle}

On completion of every irrigation cycle it is always advantageous to flush the filters and clean the discs/sieves of the filters by removing them out of the filter casing (outer body) and running plenty of water for washing out the debris stuck over the discs/sieves. The sand

TIP. It is always better to discuss with qualified agronomist before making any decision on the cultural practices.

media and hydro-cyclone filters must also be flushed out. It must be ensured that fertilizer tank has been fully emptied before completing an irrigation cycle. Leakages should be fixed and suction points,/pipes and points should also be cleared for any potential blockade during upcoming next irrigation turn.

\subsection{CARE AFTER COMPLETING A CROPPING SEASON}

Once a cropping season is over, it is very important to thoroughly overhaul the systems, clean the disc and screen filters, completely flush hydro-cyclone filters and wash the sand of sand media filter after removing it outside the filter. Sand media should also be checked and replaced if the sharp edges of the media have been rounded off. It is also necessary to cover the prime-mover properly with polythene covering/sheet, if it has not to run for a longer period. Before covering the prime mover greasing of the unit may also be useful for its protection for longer period.

In case of site located in areas of heavy snow falls, before the severe weather sets in, it is advisable to empty the water storage tank. Similarly, the drain valves of filters and fertilizer tanks should be opened to drain all the water retained in it. In case of surface installation of mainlines and sub-mainlines, the flush valve should be open to drain water available in the pipe network. Lateral can be rolled back for storing in a safe place for using in the next crop season. For subsurface installation of pipe network, a drainage valve at the lowest elevation point in the field can be provided to flush/drain all the water retained in the main and submainlines under gravity. 


\subsubsection{General operational problems and troubleshooting}

Most common operational problems associated with drip/sprinkler system are leakage(s) at head unit and in the piping network, chocking of emitting devices, physical damage to the systems components etc. Regular management and care of the system may reduce the occurrence of such problems. The operator should be trained in troubleshooting, and spare parts required most often should remain on the farm so that break-down are handled effectively and immediately to avoid any undue gap during irrigation.

CARE: After completing an irrigation cycle system must be made ready for next irrigation cycle by cleaning of filters, fertigation tank, and filling of fuel tank if system is on diesel engine. Required repairs and maintainance must also be carried out during nonoperational period between two irrigation cycles.

\subsubsection{Weekly Checklist}

A detailed maintenance procedure should be adopted for HEl systems on daily, weekly, monthly and annual basis for sustainable operation of the systems. Proformae to adopt standardized maintenance checks of micro irrigation systems is attached as Annexure-C.

\subsection{CARE AND CHECKING OF PRIME-MOVER}

Prime-mover is the most essential and important part of the high efficiency irrigation system. It is highly pertinent to provide extra ordinary care and maintenance of this component of the system as it may halt the operation for many days if goes out of order. Alternative arrangements for prime-mover are recommended but the same are not easily arranged and cost effective.

\subsubsection{Electric Motor}

Electric motor as a prime-mover is least troubled option. If the connections with the electric panel/switch are secured and there are no losing joints, there is no threat for the motor. The second threat to the motor is fluctuation in the voltage that may lead to the malfunctioning of the motor. Plastic burning smell resulting from short-circuiting/burning out requires immediate attention of the operator failure which can damage the motor completely. Rewinding or replacement can take many days that can hamper the irrigation scheduling and may lead to complete failure of the crop due to non-application of irrigations. It is therefore necessary to protect the electric motor for electric short circuiting and moisture.

Sometimes ball bearing of the electric motor gets rusted if it remains non-operational for long period. The motor having this problem produces hushing sounds. It can stick or miss-alien the motor rotor, increase electric bill and reduce motor efficiency. The replacement of rusted ball-bearing can solve the problem. 
TIP: A reliable circuit breaker and appropriate connection with suitable electric wire can save from many potential damages to the electric motor.

\subsubsection{Diesel Engine}

Many systems are being operated by using diesel engine as prime-mover. It is important to use diesel engine of good quality or of a standard brand. Diesel engines, however, required more maintenance than electric motor. Operator should check the engine oil regularly and change the same when needed along with oil filter. Poor maintenance may result in poor efficiency of the engine and resultantly reduced pressure in the system, and irrigation uniformity.

\subsubsection{Diesel Filtration}

Pour the clean Hi-Speed Diesel in the Fuel Tank via the filter on the top of tank. It's better to use the malmal (muslin) cloth for the fuel pouring. Don't fill the tank up to neck and leave some space. After pouring the diesel close the tank's cap properly.

\subsubsection{Selection of Lubrication Oil and Filling Method}

Open the dip stick cap and pour the Lubrication (Mobil) Oil of Grade 50 and measure the oil level with dip stick. It should be within the range, moreover in case of excess oil there might be problem of leakage. Substandard oil can cause damage to ring and sleeve and engine oil also starts decreasing.

\section{A. Water Cooling:}

Water supply is essential for the cooling of diesel engine. There are generally 2 methods;

1. If the Diesel Engine is attached with the pumping unit of HEIS, engine's water inlet pipe may be attached with the water supply pipe of system. For this purpose, raise the water inlet pipe of the engine above from the diesel engine level and pour water in it manually when the water starts discharging from the drain outlet and then connect it with the water supply line to ensure the continuous water supply.

Note:In some cases water source may contain some impurities e.g. sand, silt; which is harmful for engine, because it may jam the cooling system of the engine.

2. A drum can also be used to water cool the engine. But care is needed for the impurities in water.

\section{B. Use of Lubrication Oil in Air Cleaner:}

1. Air pollution and dust particles are afraid to enter in engine via the screen of air cleaner. Oil stops the dust particles entering in the engine at the air cleaner and it affects engine's performance. 
2. There should be adequate oil in the filter. In $16 \mathrm{HP}$ diesel engine $150 \mathrm{ml}$ and in other models $250 \mathrm{ml}$ of grade 50 lubrication oil should be poured.

\section{Daily based Check and Repair:}

Properly check for any leakage of oil or water. If any leakage is found, get it repaired and check the level of diesel and lubrication oil.

If the exhaust pipe is releasing excess smoke and mobil oil, it depicts that valve leaf fitting position is incorrect or there is some deposition of dirt beneath it. In this condition shutoff the engine, clean the valve leaf and re-fix it properly.

Use the tool kit provided in engine tool box. Don't hit the engine parts directly with hammer and put a wooden block in between.

\subsection{MAINTENANCE OF WATER STORAGE TANK}

If water source is canal water with availability of water on rotation basis and bore size of the tubewell is of high discharge than required for HEIS, there may be a necessity to construct a Water Storage Tank (WST). Construction of WST will ensure flexible water availability to irrigator to comply with the irrigation scheduling needs under HEIS. Construction of WST also helps in conjunctive use of canal and tubewell water, particularly if ground water is marginally fit for irrigation. Accordingly, Water Storage Tanks are being constructed on about 90 percent of the sites where HEIS systems are being installed.

Water Storage Tank may be left unlined or it may be lined with different lining materials (Plastic sheets, bricks, concrete, geo-membrane etc.). Unlined water storage tanks require more care and maintenance than the brick lined if feeding the drip irrigation systems. Water Stored in WST may contain different amounts of organic (vegetative materials, algae) and inorganic (clay, silt) impurities that can vary with the water source and type of WST. Pre-season/post season maintenance of the WST and proper attentions during the operational periods greatly helps in avoiding chocking of the system besides reducing the frequency of flushing of the filters. A circular or rectangular column with sieve size 200 mesh around the suction pipe, reduces the risks of entering inert materials either organic or inorganic into the system. A suction pipe with foot valve on the entry side may also serve the same purpose besides preventing back-flow of water to the tanks as it reduces the priming needs of the pumps as well. Settling time for about two hours must be given to the canal water before start pumping to the system.

Growth of algae is a threat of serious nature that must not be allowed to grow in the WST. Algae can pass through the sieves and filters easily. It can be successfully controlled by placing a bag of copper sulphate $(0.05-2.0 \mathrm{ppm})$ in the WST. This bag containing copper 
sulphate can be dragged over the tank or if anchored, the position of it should be changed time to time to cover complete surface area of the tank.

CAUTION: Copper sulfate is poisonous to livestock and poultry, fencing of the WST may prevent any miss-happenings beside other benefits i.e. protection of WST from dust. Water containing copper sulphate should not be swallowed at any point in any case. 


\section{CLOGGING AND PREVENTION}

\subsection{GENERAL}

Clogging, one the biggest threats to drip and micro sprinkler irrigation systems, not only disturb the application uniformity of water if partially blocked the lines and severity of it may results in replacement of equipment or PVC/LDPE lines, if ignored. Treatment of the system for prevention of clogging is not an option but it is considered a compulsion especially when using drip irrigation. Quality of water and other chemicals injected into or through the system governs the customization of system flushing, its frequency and requirement of treatment (acidification and/or chlorination) in order to avoid system damage from clogging. Clogging may be aggravated with mismanagement and negligence leading to non-flushing of filters and piping networks of the system. Proper and timely management/flushing of the system is a key to protect the system from clogging hazards given in the Table 10.1.

TABLE 10.1 Water Quality Factor Affecting the Clogging of Drip Irrigation Systems

\begin{tabular}{|c|c|c|}
\hline $\begin{array}{c}\text { Physical } \\
\text { (suspended solid) }\end{array}$ & $\begin{array}{c}\text { Chemical } \\
\text { (precipitation) }\end{array}$ & $\begin{array}{c}\text { Biological } \\
\text { (Bacteria and Algae) }\end{array}$ \\
\hline Inorganic Particles & $\begin{array}{l}\text { Calcium and Magnesium } \\
\text { carbonate }\end{array}$ & Filaments \\
\hline Sand & Calcium Sulphate & Slime \\
\hline Silt & Heavy metal & \\
\hline Clay & Oxides & Microbial Decomposition \\
\hline Plastic & Hydroxides & Iron \\
\hline Organic Matter & Carbonates & Sulphur \\
\hline $\begin{array}{l}\text { Aquatic plants } \\
\text { (phytoplankot/algae) }\end{array}$ & Silicates and Sulphides & Manganese \\
\hline $\begin{array}{l}\text { Aquatic animals } \\
\text { (zooplankton) }\end{array}$ & $\begin{array}{l}\text { Oil and Other Lubricants } \\
\text { Fertilizers }\end{array}$ & \\
\hline \multirow[t]{6}{*}{ Bacteria } & Phosphate & \\
\hline & Aqueous ammonia & \\
\hline & Iron & \\
\hline & Copper & \\
\hline & Zinc & \\
\hline & Manganese & \\
\hline
\end{tabular}

Source: D.A. Bucks, F. S. Nakayama and R. G. Gilbert, 1997. Trickle Irrigation Water Quality and Preventive Maintenance. Agricultural Water Management, p. 151.

Guidelines given in Table 10.2 have been developed for the potential of water plugging. 
TABLE 10.2 Guidelines for Potential of Water Plugging Problem when Water of Various Qualities is Used with Micro-irrigation

\begin{tabular}{|c|c|c|c|}
\hline \multirow{2}{*}{ Type of Problem } & \multicolumn{3}{|c|}{ Hazard Level } \\
\hline & Low & Moderate & Sever \\
\hline \multicolumn{4}{|l|}{ PHYSICAL } \\
\hline Suspended solids & $<50$ ppm & 50-100 ppm & $>100$ ppm \\
\hline \multicolumn{4}{|l|}{ CHEMICAL } \\
\hline $\mathrm{pH}$ & $<7.0$ & $7.0-8.0$ & $>8.0$ \\
\hline Salt & $<500$ ppm & 500-2000 ppm & >2000 ppm \\
\hline Bicarbonate & & $<100$ ppm & \\
\hline Manganese $^{1}$ & $<0.1 \mathrm{ppm}$ & $0.1-1.5 \mathrm{ppm}$ & $>1.5$ ppm \\
\hline Total Iron ${ }^{1}$ & $0.2 \mathrm{ppm}$ & 0.2-1.5 ppm & $>1.5$ ppm \\
\hline Hydrogen sulfide & $0.2 \mathrm{ppm}$ & 0.2-2.0 ppm & $>2.0 \mathrm{ppm}$ \\
\hline \multicolumn{4}{|l|}{ BIOLOGICAL } \\
\hline Bacterial population & $\begin{array}{l}<2,642 / \text { gal } \\
<10,000 / L\end{array}$ & $\begin{array}{r}2,642-13,210 / g \\
10,000-50,000 / L\end{array}$ & $\begin{array}{l}13,210 / \mathrm{gal} \\
>50,000 / \mathrm{L}\end{array}$ \\
\hline
\end{tabular}

1. When testing from iron and manganese, acidify the water sample to a $\mathrm{pH}$ of 3.5 immediately after taking it.

Source: Bucks and Nakayama, 1980

Review of the Water analysis report of the site, particularly before installation of new drip system may provide information regarding possible problems.

\subsection{CAUSE OF CLOGGING AND PLUGGING}

The major causes of plugging are listed below;

- Impaired Water Quality

- Inefficient filtration (wrong selection of filters or flushing less than required

- Selection of emitting devices without considering water quality

- Running of system at low pressure

- Abrupt change in Temperature or $\mathrm{pH}$

- Reaction of chemigation leading to precipitation

- Poor maintenance

- Less acidification and chlorination than required

- Non treatment of Water Storage Tank if algae and fungi are problems. 


\subsection{SYSTEN COMPONENTS SENSITIVE TO CLOGGING}

Clogging in the lines normally occurs at the bends, joints, coupling points or at the openings of the emitters caused by deposit of minerals or in the labyrinth of the inline drippers. Kinking of pipes lateral may also cause blockades. Most of the times impurities of physical, chemical and biological nature deposits slightly at first instance at the joints and couplings or in the emitting points and partially clog the lines that seriously effects the distribution uniformity of the system. Afterwards, particularly when acidification/chlorination is ignored, particles in the water starts coagulation on already deposited particles and starts bridging to form masses large enough to clog emission devices. It resultantly may clog the system lines completely. Air pockets trapped in the lines may also block the system besides causing possible bursting of pipes. Air release valves must be installed on the proper points (mainly at the point of sudden elevation) and must be maintained regularly to prevent potential problems.

\section{TIPS:}

1. Emitter discharge should be checked periodically at least once during irrigation season to determine emission uniformity. It will give a good idea of the possible clogging hazards.

2. During Flushing water should keenly be observed to find-out possible problems that may cause clogging and thus customize flushing/acidification/chlorination requirements, accordingly.

3. Typically, It is recommended to remove the particles larger than one-tenth the diameter of the orifice or the flow passage of the emitter.

\section{Key Practices to Prevent Clogging:}

1. Treat the water before its entering into the system to make it free from all clogging hazards

2. Designer must select the proper size of emitter keeping in view of the water quality (consideration of Water Analysis Report is must before deciding the emitters size)

3. Filteration Components must be attached with system according to the water quality

4. Emitters should reveice $100 \%$ filetered water or no water at all.

5. Filter system must be maintained propoerly and checked before every irrigation cycle.

6. Filter must be flushed frequently that depends upon water quality

7. System should be flushed regularly.

8. Slow and partial clogging must be addressd immidiately to avoid total plugging of the system lines

9. Spoon-Feeding of fertilizers and other chemicals with low concentration of chemicals may also minimizes clogging threats with reduced precipitation. 


\subsection{FLUSHING PROCEDURE}

i. Run the system and wait until it attains full working/designed pressure

ii. Flush the centrifugal filter until all sand deposited in the base has drained out and clean water is starts coming out of it (if one attached to the system).

iii. Clean the sand media filter by back-flow

iv. Start with opening of the first flush valve on the mainline. Let the water flushed away and close the valve after flushing.

v. Repeat the procedure with other flush valves at the main and sub-main lines on after the other.

vi. Do not open more than one flush valve on the sub-main and main lines as it will drop the pressure and will negatively affect the proper flushing of the lines.

vii. Start opening of the lateral ends from one side of the field and end the practice to the last lateral on the other end of the field (all laterals in a section will be opened at a time). Start closing of the lateral in the reverse order after flushing.

\section{TIPS:}

1. If the water does not come out of any line (mains/submains/laterals), it means that there is a sever clogging or breakage at some point. Check the entire length for the problem and repair as necessary.

2. Trapped air is any of the air pockets may also come out at the time of flushing. There is no need to worry, let the air come out of the pipes (it is a rear happening as air can flush out with the water).

3. A complete flushing of the filters and lateral line must be done before and after the completion of irrigation seasons, and before and after every chemigation and fertigation following the standard procedure in addition to the routine flushing during the season.

\subsection{FILTRATION REQUIREMENT}

Filtration requirement is mainly governed by the physical clogging agents in the water that is being applied using micro-irrigation systems. Table 10.3 shows the filtration requirements of some selected clogging agents. 
TABLE 10.3 Filtration Requirement for Selected Clogging Agents

\begin{tabular}{|c|c|}
\hline Water Quality & Suggested Treatment \\
\hline $\begin{array}{l}\text { 1. Inorganic solids } \\
<10 \mathrm{mg} / \mathrm{L} \text { particle size } \\
>100 \mu \mathrm{m} \text { in diameter }\end{array}$ & $\begin{array}{l}\text { Remove with stainless steel screen (particles larger than one-tenth } \\
\text { of emitter orifice diameter should be screened out). } \\
\text { These particles may pass through the irrigation system if ferrous } \\
\text { and sulphur concentrations are not too high. If slug loading is } \\
\text { frequent, then automatic screen cleaning may be required. }\end{array}$ \\
\hline $\begin{array}{l}>10 \mathrm{mg} / \mathrm{L} \text { particle } \\
\text { over or under } 100 \mu \mathrm{m}\end{array}$ & Automatic cleaning of screens suggested \\
\hline $\begin{array}{l}\text { 2. Organic solids } \\
<10 \mathrm{mg} / \mathrm{L} \text { particle over } \\
100 \mu \mathrm{m}\end{array}$ & $\begin{array}{l}\text { Sand filters are required. Recommended flow rate through sand } \\
\text { filter is } 20 \mathrm{gpm} / \mathrm{ft}^{2} \text { of bed area. Manual back flush should be } \\
\text { satisfactory. }\end{array}$ \\
\hline $\begin{array}{l}>10 \mathrm{mg} / \mathrm{L} \text { particle over } \\
100 \mu \mathrm{m}\end{array}$ & $\begin{array}{l}\text { Sand filter with automatic back flushing are required. } \\
\text { Recommended flow rate through sand filter is } 20 \mathrm{gpm} / \mathrm{ft}^{2}(815 \\
\left.\text { lit } / \mathrm{min} / \mathrm{m}^{2}\right) \text { of bed area }\end{array}$ \\
\hline $\begin{array}{lcr}\text { Slug } & \text { loading } & \text { of } \\
\text { organic } & \text { solids } & \text { with } \\
\text { particles } & \text { under } & 100 \\
\mu \mathrm{m} & & \end{array}$ & $\begin{array}{l}\text { High-suspended solid leading of this type of material through the } \\
\text { drip irrigation system. In this situation, sand filter will remove a } \\
\text { large volume of material. Automatic back flushing of the sand filter } \\
\text { will most likely be required. } \\
\text { Treatment with chlorine may be required periodically during the } \\
\text { season to prevent accumulation of particles under } 100 \mu \mathrm{m}\end{array}$ \\
\hline
\end{tabular}

Source: British Columbia Ministry of Agriculture, 1982. Water treatment guidelines for trickle Irrigation.

\subsection{SELECTION OF FILTERS}

Filters are components of prime importance particularly for drip irrigation. Poor filtration may badly affect the irrigation uniformity and successful operation of the system. Water quality in particular and amount of water to be filtered in general are the main factors that govern the selection of the filters which are of various types, shapes and sizes including, Gravel Filters, Hydro-cyclone Filters, Disc Filters and Screen Filters. The types of filters that can be selected on the basis of water quality and minimum filtration requirements for different emission devices are given in Tables 10.4 and 10.5 . 
TABLE 10.4 Filtration and Chemical Treatments Required for Different Water Sources and Clogging Agents

\begin{tabular}{|c|c|c|c|}
\hline Problematic factor & Water Sources & \multicolumn{2}{|c|}{ Filter Type and Chemical Treatment } \\
\hline Sand & Well & Hydro-cyclone & Only filtration is \\
\hline $\begin{array}{l}\text { Bacteria (Iron, Sulfur, } \\
\text { Manganese) }\end{array}$ & Well & $\begin{array}{ll}\text { Disc } & \text { Filter/Screen } \\
\text { filter } & \end{array}$ & Chlorination \\
\hline $\begin{array}{l}\text { Clay, Silt, and Organic } \\
\text { matter }\end{array}$ & Canal Water & $\begin{array}{l}\text { Hydro-cyclone } \\
\text { and/or Gravel filter }\end{array}$ & Chlorination \\
\hline Algae, Organic matter & Reservoir & $\begin{array}{l}\text { Gravel filter and Disc } \\
\text { Filter/Screen filter }\end{array}$ & Chlorination \\
\hline Algae, Organic matter & $\begin{array}{l}\text { Effluent water at } \\
\text { Secondary treatment }\end{array}$ & $\begin{array}{l}\text { Gravel filter and Disc } \\
\text { Filter/screen filter }\end{array}$ & Chlorination \\
\hline $\begin{array}{l}\text { Dissolved Salts/Iron } \\
\text { etc. }\end{array}$ & Well & $\begin{array}{l}\text { Dissolved salts can } \\
\text { pass through all } \\
\text { filters }\end{array}$ & Acidification \\
\hline
\end{tabular}

TABLE 10.5 Minimum Filtration Requirements for Different Emission Devices

\begin{tabular}{|c|c|c|c|c|}
\hline \multirow{2}{*}{$\begin{array}{c}\text { Emission } \\
\text { Device }\end{array}$} & \multicolumn{2}{|c|}{ Orifice Size } & \multirow{2}{*}{ Screen Mesh } & \multirow{2}{*}{ Sand Media Selection } \\
\hline & Inch & Microns & & \\
\hline \multirow[t]{5}{*}{ Micro-Jet } & 0.03 & 760 & 150 & \# 16 silica sand \\
\hline & 0.04 & 1120 & 80 & \# 8 crushed granite ${ }^{a}$ \\
\hline & 0.05 & 1270 & 80 & \# 8 crushed granite \\
\hline & 0.06 & 1525 & 80 & \# 8 crushed granite \\
\hline & 0.07 & 1780 & 80 & \# 8 crushed granite \\
\hline Bi-Wall & 0.019 & 480 & 200 & \# 20 silica sand \\
\hline \multirow[t]{4}{*}{ Microtube } & 0.020 & 500 & 200 & \# 20 silica sand \\
\hline & 0.025 & 635 & 150 & \# 16 silica sand \\
\hline & 0.035 & 890 & 100 & \# 11 crushed granite \\
\hline & 0.045 & 1140 & 80 & \# 8 crushed granite \\
\hline \multirow[t]{2}{*}{ Vortex } & & & 100 & \# 11 crushed granite \\
\hline & & & 200 & $50 \%$ \# 30 silica sand \\
\hline Via flow & & & 200 & $50 \%$ \# 20 silica sand \\
\hline \multirow{2}{*}{ Submatic } & 0.02 & 510 & 200 & \# 20 silica sand \\
\hline & 0.03 & 760 & 150 & \# 16 silica sand \\
\hline Dripeze & & & 200 & \# 20 silica sand \\
\hline $\begin{array}{l}\text { All long Flow } \\
\text { path emitters }\end{array}$ & & & 200 & \# 20 silica sand \\
\hline
\end{tabular}

a: Emission devices with orifice larger than 1,000 microns may not require a sand filtration system (except in extreme circumstances) but should always have atleast a \# 80 or \# 100 mesh installed. 
Source: British Columbia Ministry of Agriculture, 1982. Water treatment Guidelines for Drip irrigation.

\subsection{CLEANING OF FILTERS}

All types of filters may be cleaned from the debris entrapped in them. It is recommended to wash the filters when pressure difference on the inlet and out let of the filters increases more than 5 meters. Beyond this pressure difference there are chances that filtered contents deposited in the filters may start entering into the system or may damage the filter components (screen, discs) etc. The cleaning procedure of each filter is given in the following:

\subsubsection{Flushing of Hydrocyclone Filters (Sand Separator)}

If system is running for flushing of the filter by opening of the valve at the drain it can remove the sand deposited on the bottom of the filter but it may not be sufficient to clean all the sand. Sometimes bottom container has to be opened to remove the sand completely by hand but it must be done when system is not in operation.

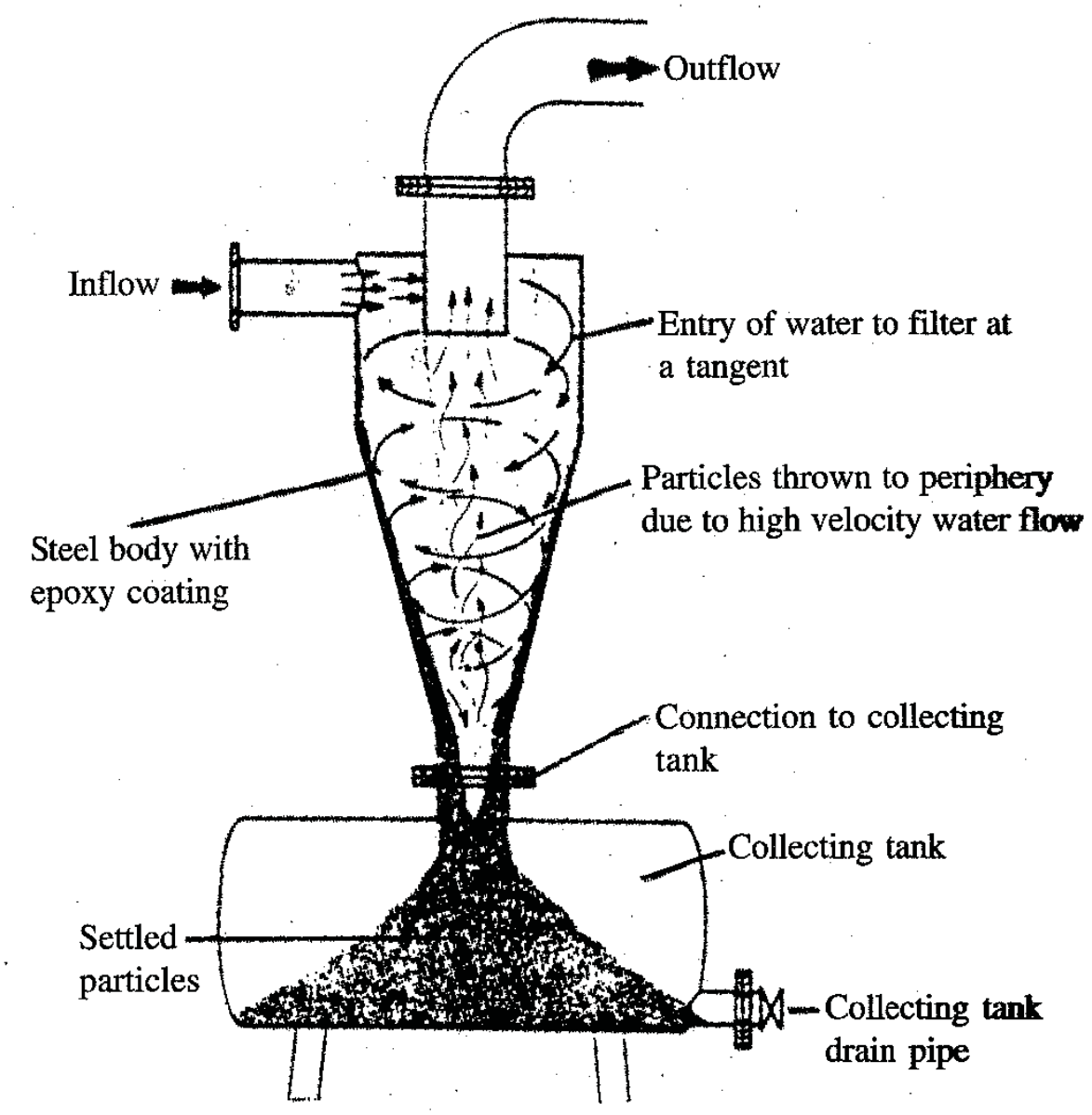




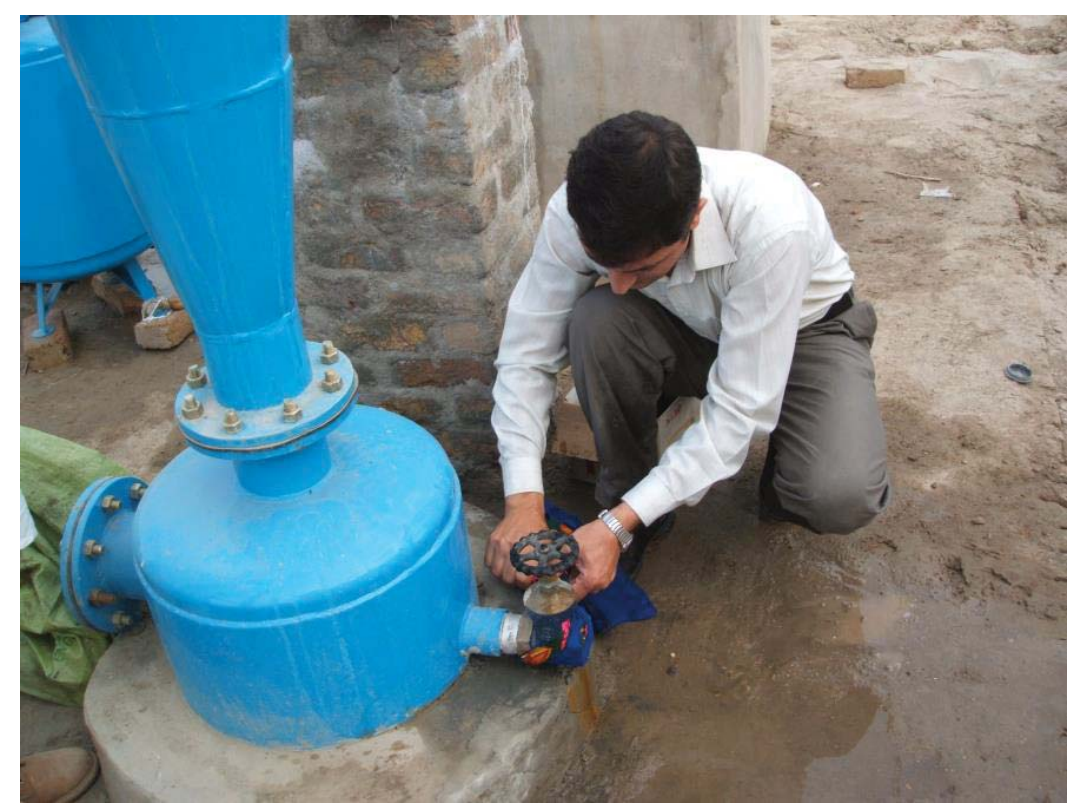

\subsubsection{Washing of Screen Filter}

Disc or screen filter can only be cleaned when system is not running. The disc/screen has to be pulled out of the covering body of the filter. Screens can be washed by running plenty of water over it. If some debris or thread like material does not come out of the screen by simple washing soft nylon brush alongwith washing with plenty of water over the screen can be used to remove the contents (Do not use hard wired brush). Casing of the filter should also be washed by back-flushing before putting the screen in it after cleaning.

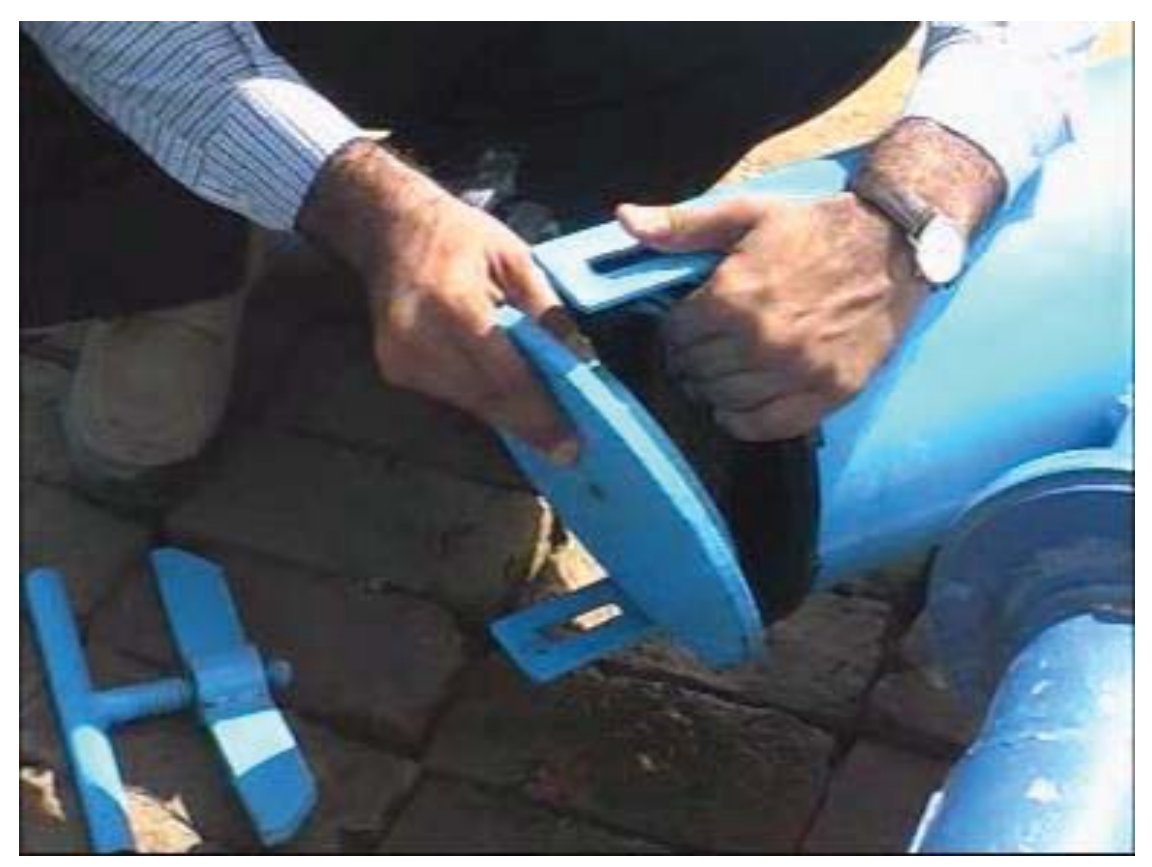




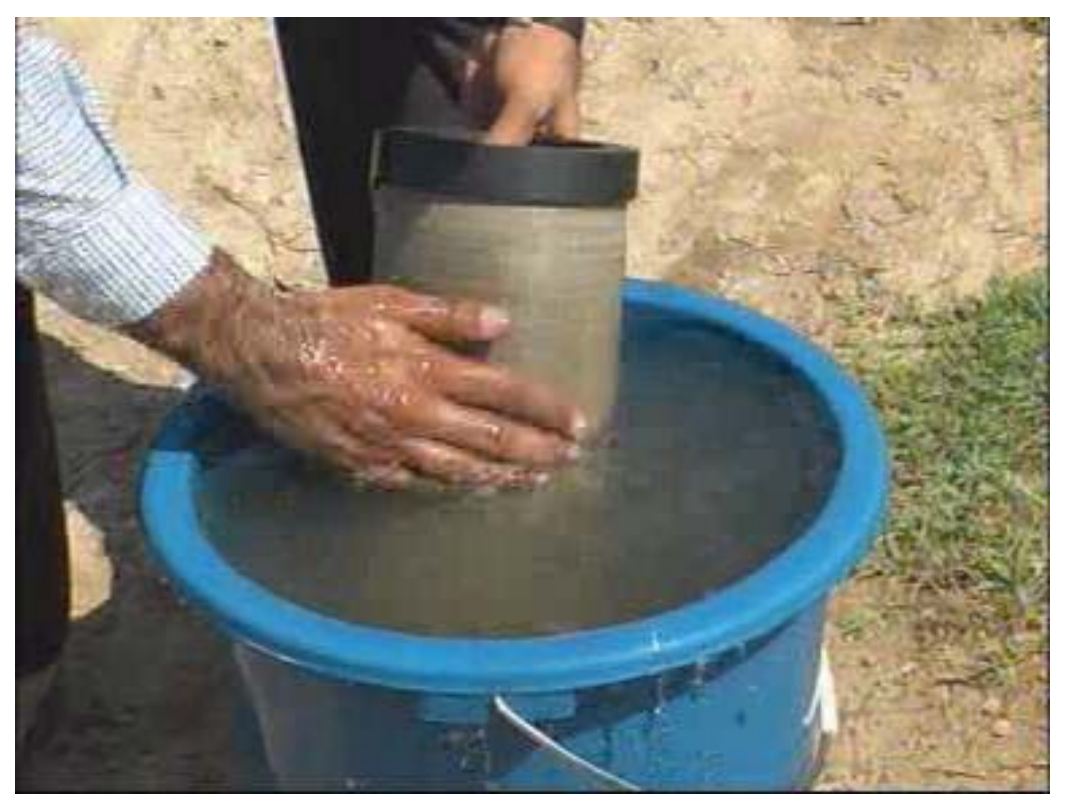

\subsubsection{Cleaning of Disc Filter}

The cartage containing discs can be removed out of the filter body and can be rinsed with plenty of water. It must be ensured to loose the discs to separate them apart by unscrewing tightening nut on the cartage bar passing through the discs to separate the discs. Discs can be cleaned by running water thoroughly. Filter body should also be cleaned to remove all organic or inorganic particles deposited in the base. It must be ensured that discs have been tightened once again before put back in the filter body. If there are any broken discs these must be replaced with the new ones.

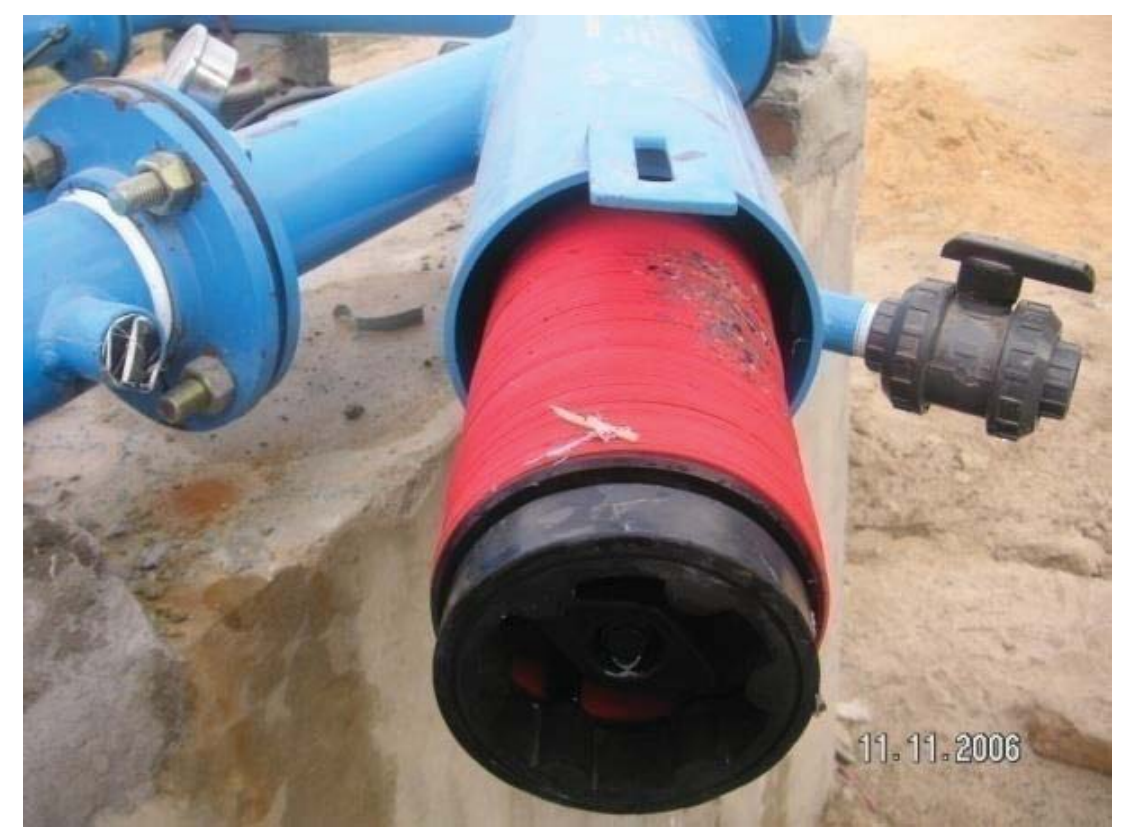



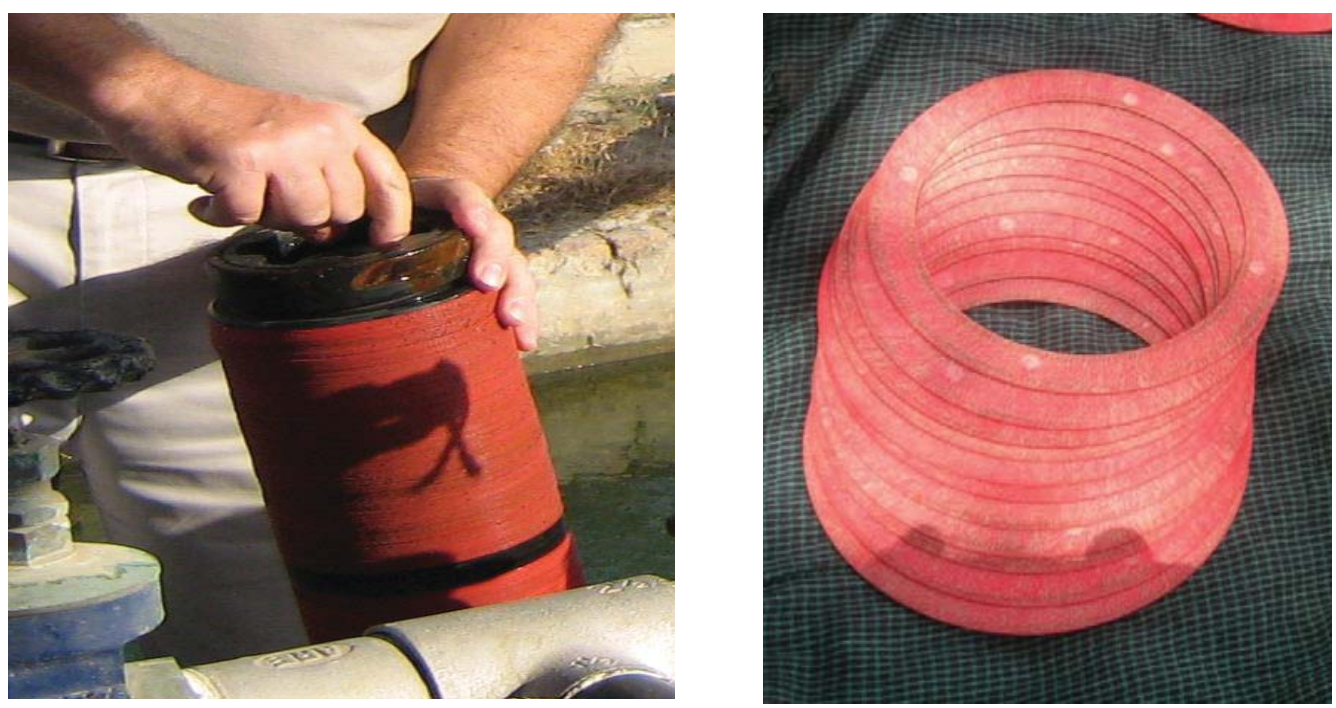

\subsubsection{Back Flushing of Sand Media Filters}

During irrigation cycles these filters have to be cleaned many times depending on the pressure difference created at the inlet and out let of the filters. Filter can be cleaned by reversing the flow direction and by passing the flow and the process is called back-flushing, as given in the following:

i. close the inlet valve from the pump

ii. close fertilizer tank valve and outlet valve to screen filter

iii. open back flushing valve to sand media filter

iv. Adjust opening of bypass valve (it is fitted from the pump to the inlet of sand filter in such a way that sand should not come out of the filter due to lifting. During back flushing, reverse water flow will lift the remedies of sediments deposits, which are lighter than sand particles.

v. Sometimes agitation/stirring of the sand is required by hand to break the lumps by squeezing.

vi. After few minutes, reverse all valves positions and then the whole system is filled with water.

vii. Measure the pressure differential at the inlet and the out lets to ensure that filter has been cleaned. If not, repeat the procedure once again. 
TIPS:

1. If despite of back-flushing the sand media, pressure differential increases with little flow of water through the filter, remove the sand out off the filter and thoroughly wash outside the filter and put it back after complete washing.

2. The sand in the media filter (crushed silica sand) must be replaced if the corners of the sand media have been rounded off as in such condition it will not be able to trap the impurities efficiently and frequency of back flushing will be increased.

3. Do not disturb the assembly at the bottom of filter while agitating soil by hand.

4. Add new silica sand if it is below the mark

5. Never use ordinary river sand in the filter

\section{BACKWASHING SAND MEDIA FILTER} Backwashing Mode

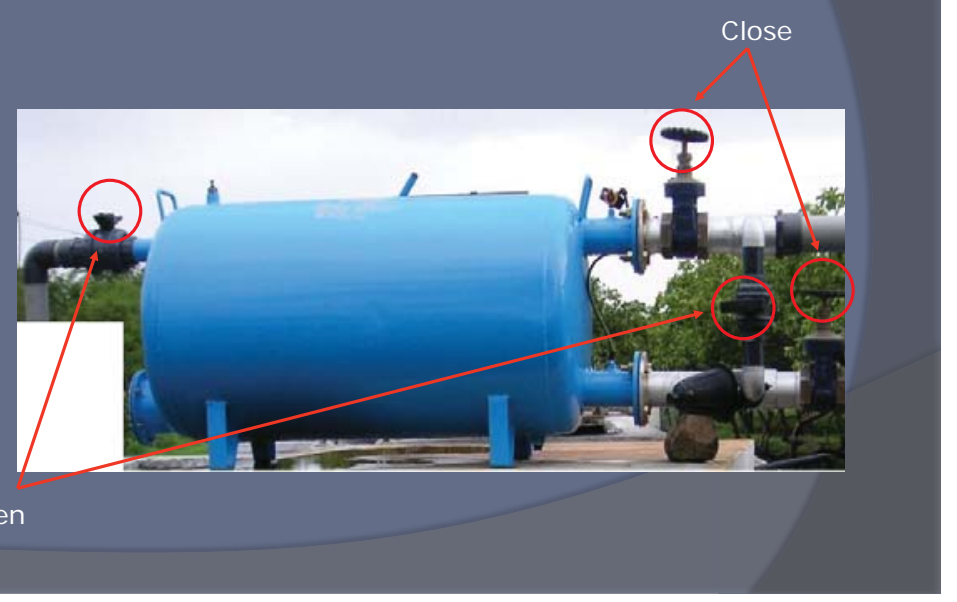

\subsection{SYSTEM RE-ADJUSTMENT - POSSIBILITIES AND LIMITATIONS}

A well designed system normally does not need any readjustments. Systems are mostly designed in a tailor made fashion and system discharge and components are selected keeping in view a particular crop, for a particular farm layout and for a particular water source to satisfy farmers needs. This leaves a very little room in order to make any amendments in the system, particularly in micro irrigation systems. Operators also advised not to make any changes themselves without consulting with the irrigation engineers/specialists. Minor changes in the system layout like change in the size of the section (if flow rate to that section allows), changes due to change in the crop, planting of new plants in between already existing plants and addition of more drippers can be made but it is not recommended to make any change without prior consultation with the irrigation specialists. 


\subsubsection{Detaching Laterals/Emitters}

Emitter once punched in the line should not be removed for maintenance. The cleaning of the emitters, if required, should be done without pulling out the drippers. Simple tapping of the dripper sometimes solves the problem if clogging is not of serious nature. Serious clogging required other corrective measure e.g. chlorination and acidification.

TIP: If all laterals have to be removed and fields/sections are of variable lengths, numbering the laterals and their take-off point can greatly help at the time of re-joining the lateral at the advent of next cropping season.

Laterals have to be removed some times, particularly at the end of the cropping season. It is important to gently pull the line to remove from the joiner and should not be twisted. Extra care is needed as putting extra force can lead to pulling out the GTO from the sub main although it is a rarity.

\subsubsection{Making New Outlets}

Although it is very uncommon to make new outlets in the sub-mains and laterals, once the system has been installed but if system capacity allows, farmer may like to add some extra lines within or outside the area already under the drip/sprinkler irrigation system. In such case after making new outlets, it is highly imperative to flush the system completely in order to remove the plastic particles out of the system which may have dropped into the lines and cause blockage at any time.

\subsubsection{Plugging of Unnecessary Outlets}

Some time making adjustment in the systems requires creating new holes and plugging of old outlets wrongly made by the installer. Putting stop plugs may solve the problems. These point closed by stop plugs may however be routinely observed for leakages.

\subsection{ENHANCING SYSTEM CAPACITY}

Once designed and installed systems have very limited or no scope for enhancement in the capacity unless heavy investment is made. Many farmers feel hesitation on the fist instance to bring their entire holding under HEIS and to get systems of large capacity. After using the system successfully for some time and get confidence in the technology they would like to enhance the capacity of the system to increase the area under drip/sprinkler irrigation system. Sometimes farmers change their cropping pattern from the crop having low crop water requirement to high Crop Water Requirements, which necessitate enhancement of the system.

Farmers' wish to enhance the capacity of their system may have to replace all or most of the system components. Supply companies may however be checked for the options as some of the firms provide solutions for up-gradation of the systems by purchasing old systems (which are sold to other interested farmers) and provision of complete new or new components of system need replacements in order to up gradate the system. 


\subsection{REPAIRS AND REPLACEMENTS}

Wear and tear of the system components are the routine matters in high efficiency irrigation systems. The systems may be repaired and if repairs are not possible, replacement of some components may be needed. The replacements must be made with the equipment of same standards and specifications. Assistance from the Supply Company should be acquired for requisite replacements.

\subsection{TOOLS}

- Farmer should keep following tools handy at the farm for maintenance of the system as and when required.

- Pipe wrench (No. 18, 24 or 36)

- Spanner set

- Drill machine with Drill bits (if not available, can be achieved on rental basis)

- Screw driver and Pliers

- Hand saw blade with frame

- Measuring tap

- Ejecto punch with refills

\subsection{SPARE PARTS}

It is necessary to keep some spare parts at the farm to avoid any unnecessary break down in the systems. Sometime systems components of minor nature can stop the system operation which cannot be afforded by the farmers particularly during periods of peak requirement. It is necessary to keep spare parts which are needed by the farmers mostly. Some of them include the following:

- Emitters/drippers/bubblers

- Screens of screen filter and discs of disc filters

- Joiners

- End caps/stop valves

- Engine/motor belts

- Silica sand

- Few extra lateral lines

- Air release valve

- Lubricants for diesel engine/motor/pump

- Gaskets for the lids of fertilizer tank/sand media filters

- Pressure gauges

- Extra sets of soft pipes

\section{Storage of spare parts}

- $\quad$ Spare parts must be stored near the system under lock and key and in the shadow.

- $\quad$ The spare parts must be protected from the damage from rodents.

- Once any spare part is used the stock should be update/maintained, immediately. 


\section{MAINTENANCE OF SAFETY EQUIPMENTS}

The system should have sufficient pressure testing points so that an overall check of the system pressures can be made. Widely differing pressures in different sections of the system may indicate that some blockage, leakage or other problem has arisen in some section of the system. Pressure checks should be regularly made, and the pressures recorded. System flow meters should be installed on the main supply lines, and should provide readings of both instantaneous and cumulative flow. These meters should be read regularly and the readings kept in a log book. Variations in the system flow rate may indicate that something in the system is amiss. For example, a gradual decline in system flow rate as measured by the flow meters may indicate a problem with the pumping station, or a clogging problem in the field. On the other hand, an unexpected increase in the system flow rate might be an indication of a pipeline break or the presence of leakage in the system. Measurements of cumulative flow will serve to verify water application schedules.

\section{MAINTENANCE OF SUBMAINS AND LATERALS}

Rocks, plant stalks and roots will tend to pinch the tube. Rats, ants and vandals cause significant damage in some areas. The tube must withstand exposure to chemical fertilizers, chlorine and pesticides. A program of routine maintenance will discover damage to the system and may help prevent further damage from occurring. A general decrease in flow rates may be the first symptom of a potentially major biological or chemical clogging problem within the system. This type of problem is far easier to treat if caught in the early stages. In many micro-irrigation systems it has been found that provisions must be made to flush submain lines and lateral lines to remove settled sediments, and thus flushing constitutes an important maintenance routine. Research has shown that most settled sediments can be flushed from pipe or tubing with a flow velocity of one foot per second, which is referred to as the "scour velocity". In standard half-inch lateral lines, the $1 \mathrm{ft} / \mathrm{sec}$ scour velocity is equivalent to a flow rate of $1 \mathrm{gpm}$ at the downstream end. Submains and lateral lines should be manually flushed several times during the season. Open the ends of the lateral lines while the system is running and allow water to run into a container until it runs clear. Collect some of the dirty water in a glass jar, and examine it carefully. Take note of the nature of the impurities in the water. If there is a significant amount of contaminant in the flush water, find out what it is. Does it appear to be a bacterial slime? Are large aggregated particles present? Is there evidence of iron precipitation? Is there any material which could be sand from the media filter. 


\section{CHEMIGATION}

\subsection{GENERAL}

Chemigation is an objective injection and application of agro-chemical including fertilizers, herbicides (weedicides), insecticides, fungicides, growth retardants/inhibitors, acids and chlorine into or through the irrigation systems. Specific fertigation components are attached with the system to inject these chemical into the mainline which flows to the plants with the irrigation water. The objectives of fertigation are provision of nutrients and others agrochemicals precisely to the root zone to fulfill actual needs of the plants, crop protection measure and/or control of weeds besides system maintenance measures. The other benefits of the chemigation are economical application of chemical as frequently as required in addition to less damage to the crop and applicator. Chemigation also reduces the soil compactness due to less movement of the machinery for spraying in the field. Chemigation is further specifically categorized according to the chemicals being applied such as Acidification, Chlorination, and Fertigation are the further denomination of chemigation if acid, chlorine or fertilizers are being injected into the system, respectively.

\section{EMITTER CLOGGING}

The biggest potential problem facing the operator of a micro-irrigation system is emitter clogging. Because the water passages in most emitters are very small, they easily become clogged by particles of mineral or organic matter. This can reduce emission rates, cause non-uniformity of water distribution and thereby cause stress and damage to plants. In some cases, contaminants are present in irrigation water delivered to the user and are not adequately filtered out. These contaminants may include soil particles, living or dead organic materials, and scale from rusty pipes. The solution to a particular clogging problem must be based upon the nature of the problem. Acid treatment has been used successfully to dissolve manganese, iron and calcium precipitates, and chlorine has been used to decompose organic materials. Where possible, allowing the system to thoroughly dry out will sometimes serve to shrink organic materials enough to partially open clogged emitters or orifices, which can then be treated more effectively with chemicals.

\subsection{ACIDIFICATION - REMOVAL OF MINERAL DEPOSITS}

The major objective of running the acids through the systems are prevention of partial or complete clogging which can be caused by the suspended solids and dissolved salts of calcium and magnesium in the water. If the irrigation water is alkaline $(\mathrm{pH}>7)$ the calcium and magnesium salts may deposit inside the system lines and may block emitters. In addition, on completion of irrigation cycles these salts may also dry-out at the outlets of the dripper generally in the form of white crust. This problem can be identified by putting drop of acid on the dripper. If the deposit fizzes, it will confirm that salts are accumulating. High contents of Iron in water on oxidization change to solid form and may clog the system, if escape filters. It can however be seen as red rust color in any system. Manganese may also cause blockage in the system components like valves, filter, main line and laterals. 
Acidification of any system depends upon the quality of water. By using the system for few months operator can assess the frequency of the acidification requirements. The typical acids which are used for acid treatment as follows:

- Sulfuric acid $\left(\mathrm{H}_{2} \mathrm{SO}_{4}\right) 98 \%$ concentrated.

- Hydrochloric acid (HCL) $35 \%$ concentrated

- Nitric Acid (HNO, 60\% concentrated

- Phosphoric Acid $\left(\mathrm{H}_{2} \mathrm{PO}_{4}\right), 85 \%$ concentrated (also used as phosphorus fertigation). If there is more than $50 \mathrm{ppm}$ calcium and $0.5 \mathrm{ppm}$ Iron in the water, phosphoric acid should not be injected because of possibilities of calcium phosphate precipitation, which cannot be dissolved with subsequent acid treatment.

- Urea-Sulfuric (e.g. N-phuric) nitrogen fertilizers that provides both acid and fertilizer

IMPORTANT: After a desired acid has been inject in the system and distributed throughout the irrigation system, turn off the system and let the low $\mathrm{pH}$ water remain in the lines for several hours, preferably overnight. This will allow sufficient reaction time to dissolve miner precipitates. After the setting period, flush the lines to remove dislodged and solubilised material.

CARE: Always add acid to Water. Do not add water to acid. All acid are dangerous to handle, and appropriate eye protection, hand gloves and protective clothing should be worn.

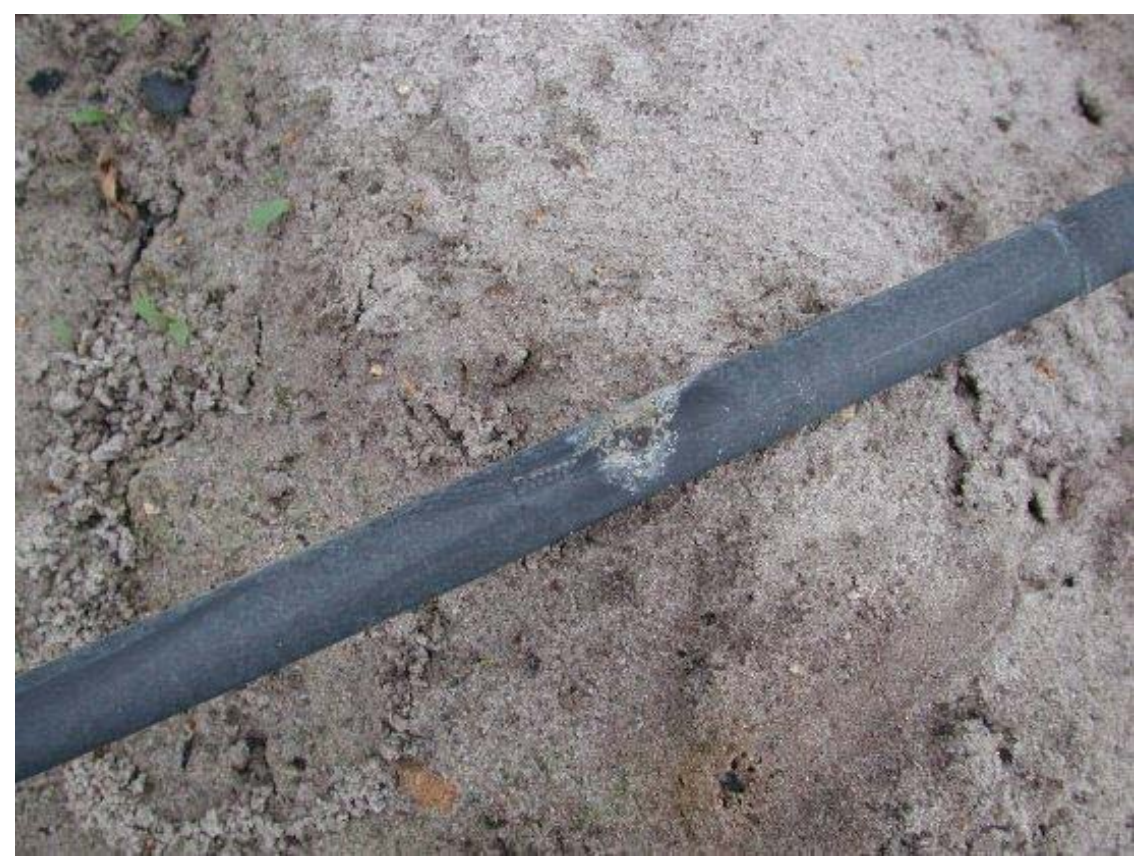

\subsubsection{Calibration for Acid Application}

Requirement of the acid can be calculated by adopting the procedure given in the following: 
- Add a liter (one liter) of water in a container (water should be taken from water source that will be used for irrigation)

- Add acid drop by drop by using pipette/dripper (pipette is better as it will show the exact quantity of acid used)

- Stir the water well after putting few drops

- Check the $\mathrm{pH}$ of water with $\mathrm{pH}$ paper (dip the $\mathrm{pH}$ paper in the acidified water and check the $\mathrm{pH}$ by matching the $\mathrm{pH}$ paper with color scale).

- Continue addition of acid, till pH of the water becomes 3 .

- Calculate the water that will pass through the system in 15 minutes (or the time for which acid treatment is to be given) using the designed discharge

- Calculate the quantity of acid required for treatment of a selected section.

Note: Example calculations are provided in the Annexure-D.

TIPS:

1. If the size of the sections (Hydrozones) is not equal, calculation for acid treatment may be need for each section depending upon the irrigation scheduling.

2. $\mathrm{pH}$ may also be checked at few dripper as well to ensure the desired $\mathrm{pH}$ level of water.

3. System must be run prior to acidification at least for half an hour

4. Do not turn off irrigation immediately after acid treatment. Let the system running at least for one hour after completion of acid treatment.

5. Keep farm animals and individuals out of the irrigated area during and after acidification/chlorination. DO NOT ALLOW WATER TO BE DRUNK..

6. Place signboards displaying the hazard information.
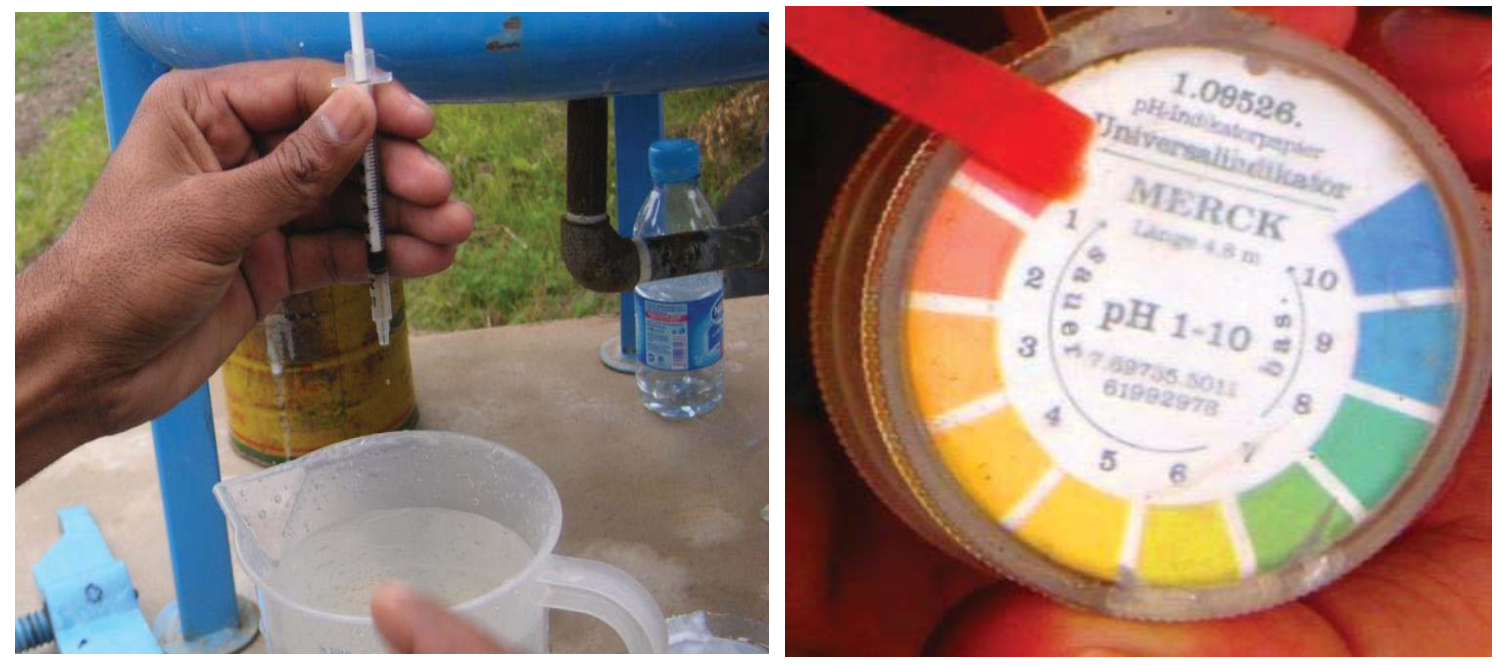

\subsubsection{Frequency of Acid Treatment}

Frequency of the acid treatment mainly depends on the water quality (salt contents in water), fertilizer being applies, and operational hour of the system. Electrical Conductivity Test or reading of EC given in the Water analysis report can help in deciding the frequency of treatments. Acid treatment is recommended if the EC values of the water is higher than 0.5 . Generally speaking, periods after which acid treatments are recommended on the basis of water quality is given in Table 11.1. 
TABLE 11.1 Frequency of Acidification based on the EC value

\begin{tabular}{|c|c|}
\hline EC value & Frequency of acidification \\
\hline Upto 1.0 & 45 days \\
\hline 1.0 to 1.5 & 30 days \\
\hline 1.5 to 2.5 & 15 days \\
\hline Above 2.5 & Water Treatment is needed before using for drip irrigation \\
\hline
\end{tabular}

Note: Frequency may vary if fertigation includes potash (MOP, SOP), phosphoric acid, and Ammonium Sulphate. If urea is applied acid treatment should be applied as per recommended schedule.

\subsection{CHLORINATION - REMOVAL OF ORGANIC/BACTERIAL CLOGGING HAZARDS}

Likewise, acidification, the objective of chlorination is also prevention of system and system lines from partial or complete blockage. The target hazards of the chlorination are prevention/elimination of growth followings through oxidization.

- Algae (originated in surface water supplies. Can also grow at the outlets of emitters)

- Fungi

- Bacteria

- Iron and Magnesium oxides and sulfides,

- Sulphur slime

- Root intrusion into the buried emitters.

In addition, chlorination also reduces risks of organic sedimentation and bacterial slime. Chlorination also improves filtration efficiency of sand/media filtration. Chlorination does not have any impact if the clogging hazards are inorganic substances like clay or silt particles.

Although application/concentration depends upon the severity of contamination but generally concentrations of 10-20 ppm, if applied weekly, may solve the problem related to the growth of organic matter. If free chlorine is applied concentration of about 0.5-1.0 ppm should persist at the hose end. Chlorine may be applied continuously at low dosage for effective prevention of bacterial growth.

Note: Example calculations are provided in Annexure-E. 


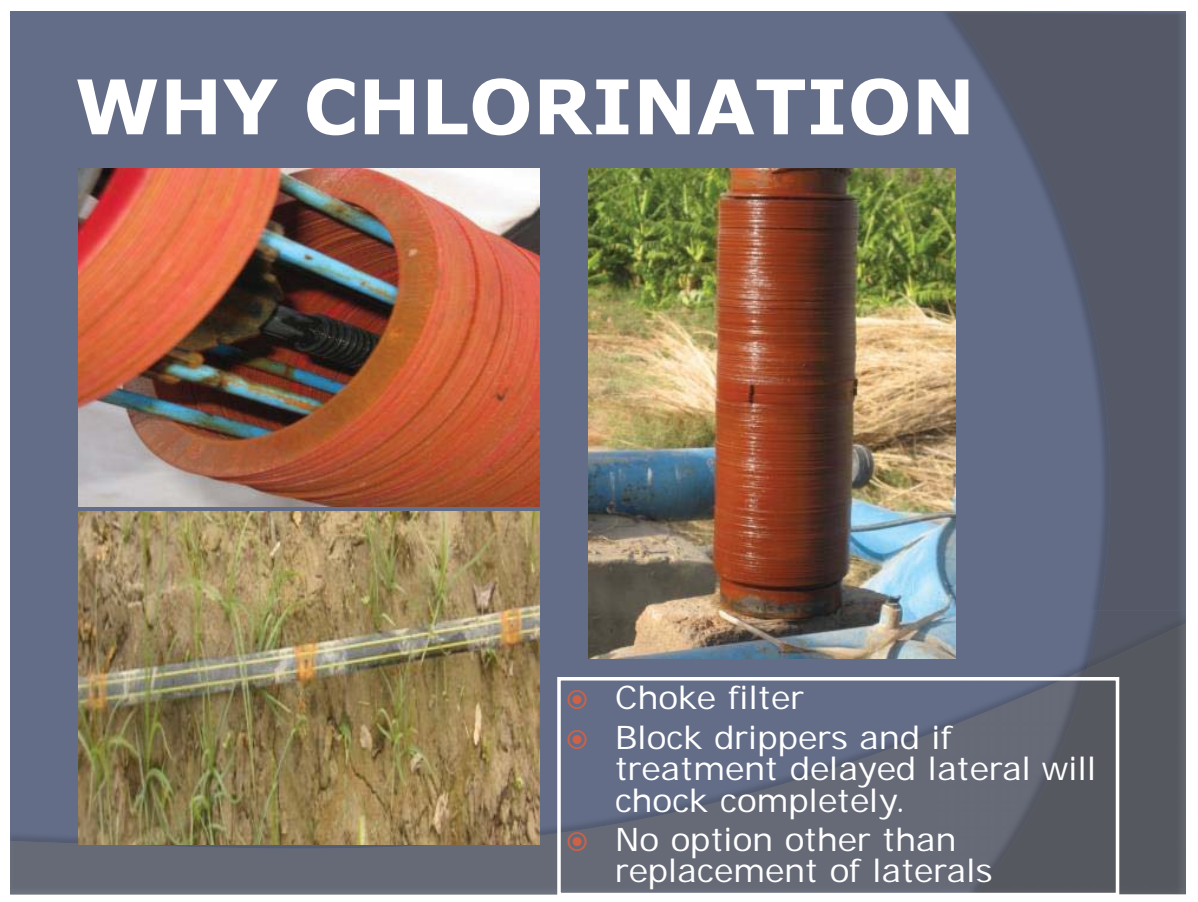

TIP: Besides the chlorination at the end and start of the cropping season, chlorination should be done fortnightly as a routine. This period can be extended or reduced depending upon the levels of build-up of organic matter.

\subsubsection{Sources of Chlorine}

Following materials can be used for fertigation:

- Bleaching Powder (CaoCl, 35\%free Cl)

- Sodium Hypo Chloride ( $\mathrm{NaOCl}, 15 \%$ free $\mathrm{Cl}$ ) (Liquid Form)

Bleaching Powder is the most easily available and cheep source of chlorination and can be easily handled compare to the liquid form as Sodium Hypo-chloride. To measure the concentration of chlorine during the treatment Chlorine Paper is used. The solution should be made by mixing of known quantity of bleaching powder in the measured quantity of water. The stock solution must be stirred vigorously to break the lumps.

CAUTION: Never mix or store acid and chlorine together

\subsubsection{Application of Super Chlorine}

Sometimes system becomes badly plugged with organic matter (particularly if remains unused for longer period) and application of chlorine at the normal concentration may not serve the purpose. In such case Super Chlorine doses (free chlorine concentration of 200$500 \mathrm{ppm}$ at the hose end) is applied. 
CAUTION: Super chlorination can damage or kill a healthy crop, so it should only be applied if there is no crop in the field.

\subsubsection{Procedure for application of Chlorination / Super Chlorination}

1. In the first instance, flush the hoses thoroughly

2. Inject the chlorine in the hoses and allow to sit-inside overnight (it is possible with flat irrigation systems; it is not possible with the system having sloping hoses).

3. Thoroughly flush the system on the next day.

TIPS:

1. Bacteria can also be killed/controlled by application of copper sulphate and citric acid or with acid fertilizers such as urea sulfuric.

2. Chemigation with Trifluralin (herbicide that can kill root tips without killing plant) may be used for prevention of roots intrusion in the sub-surface drip system

\subsection{PRECAUTIONS FOR APPLYING ACID/CHLORINE}

- Mixing acid and chlorine in the same tank will produce highly toxic chlorine gas as such acidification and chlorination should not be done collectively.

- Organic composition of herbicides/pesticides may changed by injection of these chemicals with chlorine that may reduce the effectiveness of the herbicide and pesticides.

- Always add chlorine (liquid or dry)/acid/fertilizer to water, not vice versa

- Use water from the farm water source for working out the dilution rates.

- Inhalation of fumes of acid or chlorine is also dangerous. Avoid any such practice.

- Filters/fertilizer tank and other components of the system through with water has run during chemigation must be rinse with clean water

- Backwash the sand media filter

\subsection{POST-APPLICATION MEASURES}

- Do not allow drinking of water to the human beings and farm animals and walk through the treated fields by restricting their entry.

- Flush the system completely by running the system for about an hour after the acid/chlorine treatment.

- Filters/fertilizer tank and other components of the system through with water has run during chemigation must be rinse with clean water.

- Backwash the sand media filters. 


\section{TROUBLE SHOOTING AND REMEDIES}

\subsection{GENERAL}

Farmers when operate high efficiency irrigation systems may face problems of various nature in the water storage tank, head Unit, and piping network (main and/or sub-mainlines, laterals, fittings etc.) and emitting devices. The training of farmer/operator regarding possible causes and repair and replacement will help in sustainability of the system. It is highly pertinent to take remedial measure without any loss of time so that irrigation is not disturbed. Various problems, their possible causes and remedial measures are given in Table 12.1, 12.2 and $\mathbf{1 2 . 3}$ for easy access of the information to the user.

Table 12.1 Water Storage Tank (WST)

\begin{tabular}{|c|c|c|c|}
\hline S.N & Problem & Cause & Remedy \\
\hline 1. & $\begin{array}{l}\text { Pond gets } \\
\text { emptied very } \\
\text { soon }\end{array}$ & $\begin{array}{l}\text { - Size of the tank is very small } \\
\text { and not matching with the } \\
\text { system requirement } \\
\text { - Higher percolation rate of soil } \\
\text { - Leakage in concrete floor (if } \\
\text { lined water storage tank) }\end{array}$ & $\begin{array}{l}\text { - Enhance the tank capacity } \\
\text { - Run tubewell simultaneously } \\
\text { with the system } \\
\text { - Provide geo-membrane of any } \\
\text { other lining material } \\
\text { - Check for masonry works for } \\
\text { possible repair }\end{array}$ \\
\hline 2. & $\begin{array}{l}\text { Algae has } \\
\text { been grown } \\
\text { in the WST }\end{array}$ & $\begin{array}{l}\text { - Water remained in water } \\
\text { storage tank for so many } \\
\text { days. }\end{array}$ & $\begin{array}{l}\text { - Add copper sulphate }(0.05-2.0 \\
\text { ppm). } \\
\text { - Empty the WST and let the } \\
\text { algae to die, if irrigation is not } \\
\text { needed. }\end{array}$ \\
\hline 3. & $\begin{array}{l}\text { Lot of } \\
\text { impurities } \\
\text { are entering } \\
\text { into the } \\
\text { system } \\
\text { increasing } \\
\text { filtration } \\
\text { requirement }\end{array}$ & $\begin{array}{l}\text { - Time for settling of debris is } \\
\text { not been given before running } \\
\text { a system } \\
\text { - Suction pipe is on the floor of } \\
\text { the WST } \\
\text { - Foot valve is not fixed with the } \\
\text { suction pipes or it has been } \\
\text { removed }\end{array}$ & $\begin{array}{l}\text { - Allow at least one hour for } \\
\text { settling of impurities in the } \\
\text { bottom of WST } \\
\text { - Suction pipe should be fixed } \\
\text { above the floor of the WST. } \\
\text { - Add foot valve with the suction } \\
\text { pipe. }\end{array}$ \\
\hline
\end{tabular}


Table 12.2 Head Unit

\begin{tabular}{|c|c|c|c|}
\hline SN. & Problem & Cause & Remedy \\
\hline 1. & $\begin{array}{l}\text { System is } \\
\text { not turning } \\
\text { on }\end{array}$ & $\begin{array}{l}\text { - Electricity may not be available. } \\
\text { - Wire may be unplugged } \\
\text { - Connection with the motor are } \\
\text { lose } \\
\text { - Motor rotor has been stuck due to } \\
\text { rusting } \\
\text { - No. diesel in the diesel Engine }\end{array}$ & $\begin{array}{l}\text { - Check if the electricity is available } \\
\text { - Check the electric wiring (use } \\
\text { protective gloves) } \\
\text { - Apply lubrication to the moving } \\
\text { parts of the motor and diesel } \\
\text { engine } \\
\text { - Put diesel in the fuel tank of the } \\
\text { engine }\end{array}$ \\
\hline 2. & $\begin{array}{l}\text { Low } \\
\text { discharge } \\
\text { with low } \\
\text { pressure } \\
\text { reading }\end{array}$ & $\begin{array}{l}\text { - Filters quite dirty and no proper } \\
\text { cleaning. } \\
\text { - Increased suction head due to } \\
\text { lowering of water level in the } \\
\text { source. } \\
\text { - Pump is not working properly. } \\
\text { - Leakage in pump delivery pipe. }\end{array}$ & $\begin{array}{l}\text { - Filter should be thoroughly } \\
\text { cleaned and backwash. } \\
\text { - If water level has gone down, then } \\
\text { lower the pump accordingly. } \\
\text { - Pump should be checked for its } \\
\text { working. } \\
\text { - If this doesn't then suggest new } \\
\text { pump as per requirement of head } \\
\text { and discharge. } \\
\text { - Stop leakage in pump delivery } \\
\text { pipe. }\end{array}$ \\
\hline 3. & $\begin{array}{l}\text { Pressure } \\
\text { difference } \\
\text { between the } \\
\text { inlet and } \\
\text { outlet of filter } \\
\text { is more than } \\
\text { normal. }\end{array}$ & $\begin{array}{l}\text { - Filters are not cleaned or } \\
\text { backwashed and top sand layer } \\
\text { becomes stone like hard due to } \\
\text { deposition of salts. } \\
\text { - Pressure gauge may be faulty. }\end{array}$ & $\begin{array}{l}\text { - Daily backwash the sand filter for } \\
\text { at least } 5 \text { minutes. } \\
\text { - Clean sand and screen filters } \\
\text { thoroughly by opening their lids at } \\
\text { least once in a week. } \\
\text { - Change the faulty pressure gauge. } \\
\text { - First by-pass dirty water, allow } \\
\text { only clean water in to the system. }\end{array}$ \\
\hline 4. & $\begin{array}{l}\text { Pressure } \\
\text { gauge } \\
\text { doesn't show } \\
\text { readings }\end{array}$ & $\begin{array}{l}\text { - Filters are not cleaned or } \\
\text { backwashed and top sand layer } \\
\text { becomes stone like hard due to } \\
\text { deposition of salts. } \\
\text { - Pressure gauge may be faulty. }\end{array}$ & $\begin{array}{l}\text { - To avoid rusting, cover the } \\
\text { pressure gauge with plastic sheet } \\
\text { in rainy season. } \\
\text { - If pointer is stuck, open the gauge } \\
\text { and check the pointer. }\end{array}$ \\
\hline 5. & $\begin{array}{l}\text { Venturi is not } \\
\text { working. }\end{array}$ & $\begin{array}{l}\text { - Excess / Lower pressure than } \\
\text { required. } \\
\text { - Leakages in the venturi } \\
\text { assembly. } \\
\text { - Venturi fitted in wrong (opposite) } \\
\text { direction. } \\
\text { - Pump does not generate required } \\
\text { head. }\end{array}$ & $\begin{array}{l}\text { - Set the required pressure by } \\
\text { operating the by-pass valve. } \\
\text { - Check for leakage in venturi } \\
\text { assembly and repair it. } \\
\text { - Connect venturi properly with } \\
\text { correct flow direction as marked on } \\
\text { it. } \\
\text { - Check the working of pump and } \\
\text { make necessary repairs. }\end{array}$ \\
\hline 6. & $\begin{array}{l}\text { Sand comes } \\
\text { in the screen } \\
\text { filter along } \\
\text { with trash, } \\
\text { straws etc. }\end{array}$ & $\begin{array}{l}\text { - Sand filter elements (black } \\
\text { candles) are either loosened or } \\
\text { not in the place. } \\
\text { - Improper filtration due to less } \\
\text { quantity of sand in the filter than } \\
\text { required. (i.e. below the level } \\
\text { marked on the filter) }\end{array}$ & $\begin{array}{l}\text { - Check the black candles for their } \\
\text { proper place and fit them properly. } \\
\text { - Add new sand up to the level, if it } \\
\text { is below the mark. }\end{array}$ \\
\hline
\end{tabular}


Table $12.3 \quad$ Lateral Lines

\begin{tabular}{|c|c|c|c|}
\hline S.N. & Problem & Cause & Remedy \\
\hline 1. & $\begin{array}{l}\text { Leakages at } \\
\text { GTOs in the } \\
\text { sub- } \\
\text { mainlines }\end{array}$ & $\begin{array}{l}\text { - Lateral at the start is tight without } \\
\text { sufficient allowance. } \\
\text { - Lateral pulled by cattle or people. } \\
\text { - GTOs come out or get loosened. } \\
\text { - Improper size of GTOs used }\end{array}$ & $\begin{array}{l}\text { - Keep laterals slightly loose at the } \\
\text { beginning. } \\
\text { - Cover lateral by soil or bury in soil } \\
\text { up to } 4 \text { " to avoid pulling by men } \\
\text { and cattle moving in field. } \\
\text { - Dig the soil near sub-mainline and } \\
\text { check/replace GTOs. }\end{array}$ \\
\hline 2. & $\begin{array}{l}\text { Leakages } \\
\text { along } \\
\text { lateral/Inline }\end{array}$ & $\begin{array}{l}\text { - Laterals are damaged by } \\
\text { mechanical devices or by } \\
\text { squirrels, rats, cattle, etc. }\end{array}$ & $\begin{array}{l}\text { - Small holes in the lateral can be } \\
\text { closed by goof/mistake plugs. } \\
\text { - At the cut section, put joiners } \\
\text { correctly or insert adequate piece } \\
\text { of lateral with joiners. }\end{array}$ \\
\hline 3. & $\begin{array}{l}\text { No discharge } \\
\text { at the lateral } \\
\text { end. }\end{array}$ & $\begin{array}{l}\text { - Lateral line is cut or broken or has } \\
\text { folds/kinks somewhere in } \\
\text { between. }\end{array}$ & $\begin{array}{l}\text { - Check lateral along the length for } \\
\text { cuts, folds/kinks. } \\
\text { - Straighten it if folded or kinked and } \\
\text { put joiners wherever necessary to } \\
\text { repair the cuts. }\end{array}$ \\
\hline 4. & $\begin{array}{l}\text { White } \\
\text { material } \\
\text { comes out } \\
\text { through the } \\
\text { lateral ends. }\end{array}$ & $\begin{array}{l}\text { - Water contains high quantity of } \\
\text { salts. } \\
\text { - Lateral are not flushed for a long } \\
\text { time }\end{array}$ & $\begin{array}{l}\text { - Carry out acid treatment as per the } \\
\text { recommendation. } \\
\text { - Flush filters, laterals regularly once } \\
\text { in a week. }\end{array}$ \\
\hline 5. & $\begin{array}{l}\text { Bacterial } \\
\text { slime } \\
\text { material } \\
\text { comes out } \\
\text { through the } \\
\text { lateral ends. }\end{array}$ & $\begin{array}{l}\text { - Water contains algae and excess } \\
\text { iron and sulphides. } \\
\text { - Laterals are not flushed for a long } \\
\text { time. }\end{array}$ & $\begin{array}{l}\text { - Carry out chlorine treatment as per } \\
\text { recommendation. } \\
\text { - Flush filters, laterals regularly. }\end{array}$ \\
\hline 6. & $\begin{array}{l}\text { Non-uniform } \\
\text { or less } \\
\text { discharge } \\
\text { through } \\
\text { drippers }\end{array}$ & $\begin{array}{l}\text { - Clogged drippers. } \\
\text { - Drippers along the lateral are } \\
\text { removed. } \\
\text { - Algae and salt accumulation } \\
\text { inside drippers and laterals. } \\
\text { - Filters, sub-mainlines and laterals } \\
\text { are not flushed properly for long } \\
\text { time. } \\
\text { - Lateral have Folds or leakages } \\
\text { somewhere along the length of } \\
\text { lateral. Ends of some lateral may } \\
\text { be open. }\end{array}$ & $\begin{array}{l}\text { - Open the drippers and clean } \\
\text { thoroughly. } \\
\text { - Insert drippers wherever required. } \\
\text { - Filters, Laterals and sub-mainlines } \\
\text { may be flushed. } \\
\text { - Perform chemical treatments as } \\
\text { per recommendation. } \\
\text { - Remove the folds on the laterals } \\
\text { and repair leakages, if any. } \\
\text { - Put end stops at the lateral ends } \\
\text { wherever missing. }\end{array}$ \\
\hline 7. & $\begin{array}{l}\text { Leakages at } \\
\text { dripper }\end{array}$ & $\begin{array}{l}\text { - Drippers are pulled out } \\
\text { unnecessarily making holes on } \\
\text { laterals bigger than required size. } \\
\text { - Improper size of holes on laterals. }\end{array}$ & $\begin{array}{l}\text { - Small holes can be closed with } \\
\text { goof plugs. } \\
\text { - For large holes, cut lateral and } \\
\text { reconnect using joiners. } \\
\text { - Never pull drippers from laterals } \\
\text { as drippers may be opened and } \\
\text { cleaned without removing from } \\
\text { laterals. }\end{array}$ \\
\hline
\end{tabular}




\section{TROUBLE-SHOOTING}

\begin{tabular}{|c|c|c|c|}
\hline S.\# & Problem & Cause & Remedy \\
\hline 1. & $\begin{array}{l}\text { Leakage at } \\
\text { Submain GTO }\end{array}$ & $\begin{array}{l}\text {-Lateral at the start is tight } \\
\text {-Lateral pulled by cattle or } \\
\text { people } \\
\text {-GTO comes out or gets } \\
\text { loosened }\end{array}$ & $\begin{array}{l}\text {-Keep the lateral loose at the beginning } \\
\text {-Cover the lateral by soil or bury in soil up to } 4 \text {,' } \\
\text { •Dig the soil near submain and place GTO }\end{array}$ \\
\hline 2. & $\begin{array}{l}\text { Leakage along } \\
\text { the } \\
\text { Lateral/Inline }\end{array}$ & $\begin{array}{l}\text { Lateral/inline is damaged by } \\
\text { mechanical devices or rats etc. }\end{array}$ & $\begin{array}{l}\text {-Small holes in the lateral can be closed by goof } \\
\text { plugs } \\
\text {-At the cut sections, put joiners }\end{array}$ \\
\hline 3. & $\begin{array}{l}\text { No discharge at } \\
\text { Lateral/Inline } \\
\text { end. }\end{array}$ & $\begin{array}{l}\text { Lateral/Inline is damaged by } \\
\text { mechanical devices or by rats } \\
\text { etc. }\end{array}$ & $\begin{array}{l}\text {-Check lateral/Inline along the length for cuts, folds } \\
\text { •Straight the lateral and put joiners where ver } \\
\text { necessary }\end{array}$ \\
\hline 4. & $\begin{array}{l}\text { White } \\
\text { crustation } \\
\text { material comes } \\
\text { out through } \\
\text { lateral ends. }\end{array}$ & $\begin{array}{l}\text {-Water contains high quantity } \\
\text { of salts } \\
\text {-Laterals are not flushed for } \\
\text { along time }\end{array}$ & $\begin{array}{l}\text {-For salts in the form of white crustation, carry out } \\
\text { acid treatment } \\
\text {-Flush the filters, laterals regulary once in a week }\end{array}$ \\
\hline
\end{tabular}

\begin{tabular}{|c|c|c|c|}
\hline S.\# & Problem & Cause & Reme dy \\
\hline 5. & $\begin{array}{l}\text { Fibrous bacterial slime } \\
\text { material comes out } \\
\text { through lateral ends. }\end{array}$ & $\begin{array}{l}\text {-Water contains algae and excess iron } \& \\
\text { sulphides. } \\
\text {-Laterals are not flushed for along time }\end{array}$ & $\begin{array}{l}\text {-Chlorine Treatment } \\
\text { Flush the filters, laterals regulary once } \\
\text { in a week }\end{array}$ \\
\hline 6. & $\begin{array}{l}\text { Non uniform or less } \\
\text { discharge through } \\
\text { drippers }\end{array}$ & $\begin{array}{l}\text {-Clogging of drippers } \\
\text {-Algae and salt accumulation inside } \\
\text { drippers and laterals } \\
\text { •Fold or leakage has developed } \\
\text { somewhere along the lateral } \\
\text {-Ends of some laterals may be open. }\end{array}$ & $\begin{array}{l}\text {-Open the drippers and clean } \\
\text { thoroughly } \\
\text {-Remove the folds on lateral and repair } \\
\text { leakage, if any } \\
\text {-Put the en d cap at lateral end } \\
\text { wherever missing. }\end{array}$ \\
\hline 7. & $\begin{array}{l}\text { Non uniform discharge } \\
\text { with dry patches of soil } \\
\text { in the Inline system }\end{array}$ & $\begin{array}{l}\text {-Air release valve is not at proper place or } \\
\text { not working and he nce soil particles are } \\
\text { sucked in and clog the dripper holes. } \\
\text {-Algae growth in filter or Inline. } \\
\text {-Inline has cuts }\end{array}$ & $\begin{array}{l}\text {-Air release valve should be located at } \\
\text { higher points along the submain and } \\
\text { check if it is working properly } \\
\text {-Chlorine Treatment }\end{array}$ \\
\hline 8. & $\begin{array}{l}\text { Low discharge with low } \\
\text { pressure rating }\end{array}$ & $\begin{array}{l}\text {-Sand filters quite dirty and no proper } \\
\text { cleaning } \\
\text {-Increased suction head due to lowering } \\
\text { of water level in the source } \\
\text {-Dirt in volute and impeller of pump } \\
\text {-Leakage in pump delivery }\end{array}$ & $\begin{array}{l}\text {-Sand filter should be thoroughly } \\
\text { cleaned and back wash daily. } \\
\text {-If water level gone down, th en lower } \\
\text { pump accordingly. } \\
\text {-Clean the volute and impeller. } \\
\text {-Stop leakage in pump delivery pipe. }\end{array}$ \\
\hline 9. & $\begin{array}{l}\text { Excess pressure at the } \\
\text { filters. }\end{array}$ & $\begin{array}{l}\text { No provision of by-pass assembly in the } \\
\text { system. }\end{array}$ & $\begin{array}{l}\text { Install by-pass assembly before filter to } \\
\text { divert excess flow and maintain desired } \\
\text { flow \& pressure in the system }\end{array}$ \\
\hline
\end{tabular}




\begin{tabular}{|c|c|c|c|}
\hline S.\# & Problem & Cause & Remedy \\
\hline 10. & $\begin{array}{l}\text { Pressure difference } \\
\text { between the inlet and } \\
\text { outlet of filter is more } \\
\text { than normal }\end{array}$ & $\begin{array}{l}\text {-Filters are not deaned or back } \\
\text { washed } \\
\text {-Pressure gauge may be faulty }\end{array}$ & $\begin{array}{l}\text {-Back wash the sand filter for at least } 5 \text { minutes } \\
\text {-Clean the screen filters. } \\
\text {-Change the pressure gauge. }\end{array}$ \\
\hline 11. & Ventury is not working & $\begin{array}{l}\text {-Excess/lower pressure than required } \\
\text {-Leakages in the venturyassembly } \\
\text {-Ventury fitted in wrong /opposite } \\
\text { direction. } \\
\text {-Pump does not generate required } \\
\text { head. }\end{array}$ & $\begin{array}{l}\text {-Set the required pressure byoperating by-pass } \\
\text { valve } \\
\text {-Check the leakage and repairit. } \\
\text {-Connect the venture in right direction as } \\
\text { marked on it } \\
\text {-Check the working of pump and make } \\
\text { necessary repairs. }\end{array}$ \\
\hline 12. & $\begin{array}{l}\text { Sand comes in the } \\
\text { screen filter alongwith } \\
\text { straws etc. }\end{array}$ & $\begin{array}{l}\text {-Sand filters element (black candles) } \\
\text { are either loosened or not in place. } \\
\text {-Less sand than required level. }\end{array}$ & $\begin{array}{l}\text {-Check black candles for their proper place } \\
\text { and fit them properly } \\
\text {-Add new sand up to the marked level }\end{array}$ \\
\hline 13. & $\begin{array}{l}\text { Air release cum } \\
\text { vacuum release valve } \\
\text { leaks constantly. }\end{array}$ & $\begin{array}{l}\text { Valve " } O \text { " ring has deviated from its } \\
\text { base orit is worn out. }\end{array}$ & $\begin{array}{l}\text { Position the " } O \text { " ring properly or replace by } \\
\text { new one, if worn out. }\end{array}$ \\
\hline 14. & $\begin{array}{l}\text { Too high pressure at } \\
\text { the filter outlet }\end{array}$ & $\begin{array}{l}\text { Check number of hydro-zones under } \\
\text { irrigation.It could be that less blocks } \\
\text { than the recommended numbers are in } \\
\text { operation. }\end{array}$ & $\begin{array}{l}\text { Operate the system at designed number of } \\
\text { hydro-zones. }\end{array}$ \\
\hline
\end{tabular}




\section{References}

Consultants will furnish references on request. 